\title{
Notes on Orthography, Phonology and Morphology of the Quranic Consonantal Text
}

\section{A.1 Introduction}

This appendix serves as a more detailed discussion for some of the topics of the language of the Quranic Consonantal Text that have come up throughout this book. As previous works on the language and orthography of the Quran have mostly relied on the Cairo Edition, which is not always an accurate reflection of the Uthmanic Text, this appendix aims to add some more detailed discussion to questions of orthography, phonology and morphology of Quranic Arabic. Throughout the book there are several references to this appendix, but I have also included topics of note here which do not receive direct discussion in the book. It is hoped that this appendix can function as a short but useful guide to some of the main features of Quranic Arabic on its own. In some cases, discussions here rely on observations and generalizations of the orthography found in early Quranic manuscripts. Whenever I do so, I refer to Appendix B, which is a list of relevant tables that compares the orthography of certain words across early Quranic manuscripts.

\section{A.2 Orthography}

The Quranic orthography was studied in great detail by Werner Diem (1976; 1979;1980;1982) in a series of highly insightful and in-depth articles which trace the rise and development of Quranic orthographic practice from its Nabataean Aramaic origins. Diem exclusively relied on the orthography as found in the Cairo Edition, which has occasionally caused him to draw the wrong conclusions about the principles of Quranic orthography as they must have been present in the UT. Quite often, we find that early Quranic manuscripts consistently agree with each other on certain topics of orthographic practice, where the Cairo Edition differs from this practice. In this section I will discuss the main orthographic practices of Quranic Arabic, which will necessarily overlap on occasion with the observations made by Diem. 


\section{A.2.1 The Spelling of $\bar{a}$}

In Pre-Islamic Arabic written in the Nabataean script, and transitional Nabataeao-Arabic there was no way to write word-internal $\bar{a}$ (unlike $\bar{l}$, and $\bar{u}$ ). With the loss of the glottal stop in Quranic Arabic, the Palif gave rise to a new wordinternal mater lectionis for /ā/ (Diem 1979, §6o-68; van Putten 2018). ${ }^{1}$ In the QCT, the use of Palif for writing /ā/ is still largely optional, and it is one of the main points of disagreement between different Quranic manuscripts (van Putten 2019c, 281-286). Despite this unstable status of the spelling, several generalizations can be made about its spelling.

In the QCT defective spellings of $\bar{a}$ are very common, but highly uncommon in words of the shape CāC and Cā̄ (Diem 1979, §67). The exception to this being the spelling of the verb 'to say' /qāl/ which in early Islamic documents is almost without exception spelled defectively قل, an archaic spelling retained in this one high frequency word, the same is true for, for example its plural form ققلو.2 In the CE the special status of the verb qāla has almost completely disappeared, and is generally spelled plene as other verbs of this type. However, قل recited as qāla occurs in Q21:112, Q23:112,114 and Q43:24. ${ }^{3}$

The defective spelling of the feminine plural ending /-āt/ is standard in the Uthmanic orthography. In the CE only بنات 'daughters' is regularly spelled plene. Besides these there are three specific exceptions: Q41:12 سموات 'heavens' (versus

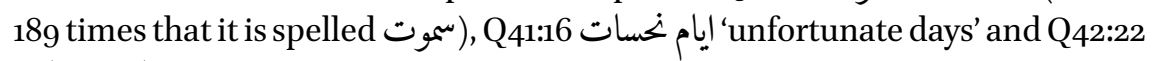
the flowering meadows of the gardens'. These unique exceptions of these verses do not seem to be a feature of the UT. For الجنات /ğannāt/ 'gardens', the plene spelling is regular in early manuscripts, just like بنات /banāt/ 'daughters', and not just used in the position Q42:22. It appears that if the stem + the feminine plural ending would only be three letters long if the feminine

1 This same feature is well-attested in early Islamic Arabic, and generally recognized to be part of Pre-Classical orthography (Blau 1967, § 9.1; 2002, 35, § 26; Hopkins 1984, § 10).

2 A lack of awareness of the special status of qâla has led to some confusion in epigraphic research. The extremely common formula اللهم اغفر [...] لمن قل/قال امين 'O God, forgive [...]

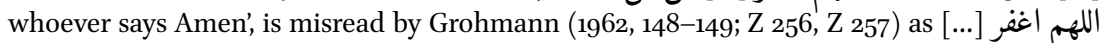
'O God, grant pardon [...] to everyone who returns, Amen'. cf. the same formula قال فال فان (al-Kilābī 20o9, nos. 78, 215) and with قل (al-Kilābī 2009, nos. 49, 90). A similar misunderstanding is found in the edition of the $31 \mathrm{AH}$ gravestone inscription from Aswan, where line استغفر له اذا قرا هذا الكتب وقل امين 5hould be understood as "and ask (Allah) pardon for him (the deceased) when he reads this writing and says Amen", and not how it is translated "(passer by) When reading this inscription ask pardon for him (the deceased) and say Amen!" (El-Hawary 1930, 322).

3 In all of these cases, the choice of spelling these defectively seems to be an attempt to accommodate the other canonical readings, which in these places disagree on the reading of this word. Some of them thus read it as qul (Ibn al-Ǧazarī, §3640, §3705, § 3706, § 4154). 
plural ending was spelled defectively, the ending is spelled plene (van Putten 2019c, 284). As for روضات نحسات ,سموات, these are normally spelled defectively in these positions, following the regular rule of defective spelling of $-\bar{a} t$ in early manuscripts (see B.1). ${ }^{4}$

In the QCT, $\bar{a}$ two syllables removed from the stress, such as in plural G-stem active participles and duals $\mathrm{C} \bar{a} C i C \bar{u} / \bar{\imath} n, C \bar{a} C i C \bar{a} t$ and $C \bar{a} C i C \bar{a} n / a y n$ (as well as العلمين /al-\{ālamīn/) are consistently spelled defectively. Diem (1979, §67.2;1980, $\S 105)$ notices this rule too, but observes that in the CE, hollow verbs break this patterns and are consistently spelled plene (as are the singulars), e.g. Q7:قايلون 'sleeping at noon'. This is however an idiosyncracy of the CE. In early Quranic manuscripts these words simply follow the same rule as other plurals of this pattern and are spelled defectively (van Putten 2018, 108f.).

The vocative prefix /yā-/ is consistently spelled defectively throughout the Quran, and this is without exception, e.g. يموسى 'O Mūsä' (Q2:55 and passim), يمريم 'O Maryam' (Q3:37 and passim), etc. ${ }^{5}$

Whenever the ipl. suffix -na is followed by any other clitic, it is consistently spelled defectively, e.g. رزقهم 'we provided them' (Q2:3), ارسلك 'we have sent you' (Q2:119).

\section{A.2.2 Questions of Double yā?, wāw and ?alif}

Diem (1979, §37-43) discusses the avoidance of double matres $y \bar{a}$ ? and $w \bar{a} w$ in detail, and argues that the sequences of $y \bar{\imath}$ and $w \bar{u}$ are typically written with only a single $y \bar{a}$ ? and $w \bar{a} w$ respectively, whereas other phonetic sequences may still have these two consonants in a row. However, the facts as they appear in the CE are not very representative of the UT, and as a result the analysis does not hold up.

For the 1 , Diem cites cases such as CE ولى /waliyy-i// 'my friend' (Q7:196; Q12:101); CE يحى /yuhyī/ 'he revives' (Q2:73) and CE يستحى/yastahyī/ 'he is ashamed' (Q2:26). However, in early Quranic manuscripts all of these are consistently spelled with two $y \bar{a}$ ?s, and therefore the UT had two $y \bar{a}$ ?s (see B.2). ${ }^{6}$

4 The common defective spelling of the feminine plural ending also occurs in early Islamic inscriptions, but is misunderstood by Grohmann (1962, Z 48), who interprets صلوت الله as a

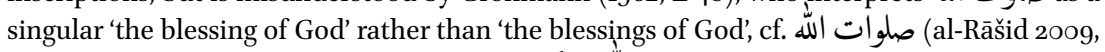
242). Likewise, Grohmann translates رحمت الله وبركته عليك the Mercy and blessing of God may be upon you' taking بركته as a singular (Grohmann 1962, Z 150, Z 171), but this formula certainly has the plural /barakāt-uh/, cf. رحمت الله وبركاته عليك (Grohmann 1962, Z 225).

5 This practice is also attested in early Islamic Papyri (Hopkins 1984, §1od), in the Ibn Wahb literary papyrus (Blau 1999, 124). Several clear cases are found in early Islamic inscriptions as well, e.g. يرحمن (al-Kilābī 20o9, no. 35), ئ my lord' (Grohmann 1962, nos. 165, 232).

6 The origin of this innovation in the Cairo Edition appears to come from Al-Dānī's al-Muqni؟ 


\begin{tabular}{|c|c|c|}
\hline & UT & CE \\
\hline Q7:196, Q12:101 & وليى & ولى \\
\hline e.g. Q2:73 & كيىى & \\
\hline e.g. Q2:26 & حيى & \\
\hline Q2:258 & & حى \\
\hline Q15:23, Q50:43 & & \\
\hline
\end{tabular}

With these forms shown to be innovations of the CE, the amount of examples where a single $\varsigma$ is used to write a sequence /yī/ becomes very small, whereas there are several more examples where a double $\varsigma$ is used even in de CE, e.g. يحييك /yuhyī-kum/ 'he revives you' (Q2:28; Q8:24; Q22:66; Q30:40; Q45:26); يحيين /yuhyī-n/ 'he revives me' (Q26:81); يكييه/yuhyī-hā/ 'he will give them life'

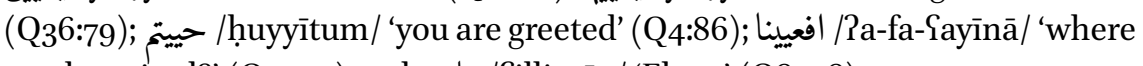
we then tired?' (Q50:15) and عليين / Filliyyīn/ 'Elyon' (Q83:18).

Diem (1979, §41) considers the outcome of baī̌s (Q7:165) spelled بيس to be a reflection of /bayis/, but it seems doubtful that this is the correct analysis. First, it is not clear that *ba?īs is the word which بيس is supposed to represent, as in the canonical reading traditions it is variously recited as bisin, bi?sin, bay?asin and ba?̄̄sin (Ibn al-Ǧazarī, § 315o). ${ }^{*}$ *bi?sin would of course yield /bīs/, for which بيس is the only acceptable spelling, and *bay?asin would presumably yield /bayas/ or / bayyas/, again بيس being the only acceptable spelling. But even if Diem is right to assume that *baīs is the origin of what بيس represents, it is quite probable that the outcome of *ba?'s after the loss of *? was not bayis but rather bayyis aligning with the outcome of the $\mathrm{CaCīC}$ adjectival pattern of hollow roots such as mayyit 'dead' (cf. Blau 1967, §11.4.1.1) for which, once again, would be the expected spelling. For these reasons this word is not a very good example of avoidance of two $y \bar{a}$ ?s in the sequence $y \bar{\imath}{ }^{8}$

The examples that are left, then all have in common that they either have they correspond to the Classical Arabic sequence $i y y \bar{\imath} / \bar{\imath} \vec{\imath} \bar{\imath}$ or $\bar{a} ? \bar{\imath}$. The examples are given below.

who mentions that the Qurans of Medina and Iraq spell these words with only one $y \bar{a}$ ? a practice copied by the Cairo Edition (Al-Dānī al-Muqni\}, ${ }_{5} 6$ ).

7 Among the non-canonical readings there are moreover reports of bay?isin, bissin, baysin and bìīs (Ibn Xālawayh muxtașar, 47).

8 One might also consider the reading /bāyis/ < "bā?isin, which would be in line with the orthography بايس attested in BnF Arabe 6140a, although this could also be analysed as a case of historical hamzah spelling see A.2.7. 


\section{The reading traditions}

\section{QCT}

\begin{tabular}{|c|c|c|}
\hline an-nabiyyīna, an-nabìīina $\left(\mathrm{Q}_{2}: 61 \text { \& passim }\right)^{9}$ & 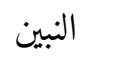 & 'the prophets' \\
\hline al-ḥawāriyyīna (Q5:111; Q61:14) & 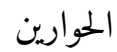 & 'the apostles' \\
\hline al-Pummiyyina $(\mathrm{Q} 3: 20,75 ; \mathrm{Q} 62: 2)$ & & 'the gentiles' \\
\hline rabbāniyyīna $\left(\mathrm{Q}_{3}: 79\right)$ & & 'worshippers of the lord' \\
\hline 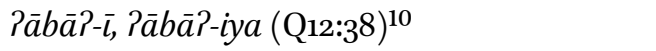 & & 'my fathers' \\
\hline warāe- $\bar{\imath}$, warā?-iya, warā-ya $(\mathrm{Q} 19: 5)^{11}$ & & 'behind me' \\
\hline šurakā?-ī, šurakāe-iya $\left(\mathrm{Q}_{41: 47}\right)$ & & 'my associates' \\
\hline$d u \oint \bar{a} P-\bar{l}, d u \varsigma \bar{a} P_{-}-i y a\left(\mathrm{Q}_{71}: 6\right)$ & دعاى & 'my prayer' \\
\hline Pisrāāê̄il (Q2:40 \& passim) & 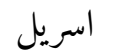 & 'Israel’' \\
\hline ğibrïl, ğabrïl, ğabraril, ğabraß̄̄l (Q2:97, 98) & & ‘Gabriel’ \\
\hline mīkāl, mīkāril, mīkāā?il, mīkāāầl (Q2:98) & & 'Michael' \\
\hline
\end{tabular}

As the apparent absence of double matres is phonetically conditioned, it seems like they should be considered the result of a genuine phonetic development, rather than an orthographic convention. In the case of the nouns that have a Classical Arabic sequence iyyina or ẗiña it is likely that we are dealing with a contraction to /-in/. Diem (1979, §39) deems this unlikely, as he argues that an oblique plural الامين/al-ummin/ should have had a nominative***al- الامون/alummūn/. To my mind, it seems perfectly possible to have an asymmetrical paradigm nom. /al-ummiyyūn/ obl. /al-ummīn/ without necessarily undergoing analogical leveling in one direction or the other. This is, in fact, a possibility in the Sarabiyyah, e.g. أعجمين Pa Sjamina 'the non-Arabs' (Fischer 2002, §116, note 2$).{ }^{14}$

As for the nouns that in Classical Arabic end in $\bar{a}$ ? followed by the 1sg. possessive marker, it seems likely that the sequence $\bar{a} \bar{p}^{-} \bar{\imath}$ or $\bar{a}$ - $-i y a$ simply collapsed

\footnotetext{
9 Ibn al-Ğazarī (§1531).

$10 \quad$ Ibn al-Ğazarī (§ 2493).

11 Ibn al-Ǧazarī ( $\$ 2519)$. Warā-ya is attributed to Ibn Katīir in a non-canonical transmission (Ibn Muğahid, 407).

12 Ibn al-Ğazarī (\$ 2714).

13 Ibn al-Ğazarī (\$2715).

14 The only exception to this contraction is عليون/Silliyyūn/, عليين/Silliyyīn/ 'Elyon'. As this is likely a loanword from Hebrew 'Elyon 'upper part of something; epithet of God' (Jeffery 2007, 215-216), it should not surprise us that this contraction does not take place, as it may have been borrowed at a time postdating the contraction.
} 
to /ā-y/ after the loss of the hamzah and final short vowels. A trace of this development seems to have been retained in transmission of Ibn Katīir's reading as warā-ya.

This leaves us with جريل 'Israel', جبريل 'Gabriel' and ميكيل 'Michael'. At first sight one might want to read these as /Risrāyil/, /ğibrāyil/ and /mīkāyil/. However, because اسريل stands in a /UR/ rhyme eight times (Q7:105, 134; Q26:17, 22, 59,$197 ; \mathrm{Q}_{32}: 23 ; \mathrm{Q}_{43}: 59$ ), such a reading would break the rhyme. The reading that would be consistent with both the rhyme and the spelling is, in fact, / Pisril/, paralleling the development that we see in the majority reading of جبريل as /ğibril//. By extension it seems probable that ميكيل is to be understood as $/$ mikill/.15

While double $y \bar{a}$ ? avoidance when spelling $y \bar{\imath}$ does not appear to have been an orthographic principle, this seems to be different for double $w \bar{a} w$ avoidance when spelling $w \bar{u}$ (cf. Diem 1979, §40). In post-consonantal position, the sequence $/ w \bar{u} /$ is indeed written with a single $w \bar{a} w$. This is exemplified by forms of the verb lawā 'to distort; to turn around': يلون /yalwūn/ 'they distort' (Q3:78), تلون /talwūn/ 'you will [not] turn around' (Q3:153) and /talwū/ 'you distort' (Q4:135). ${ }^{16}$ We can likewise see this avoidance of two wāws in word-initial position we find ورى /wūrī/ 'was concealed' (Q7:20). It seems likely that we can also count فاوا /fāwū/ 'so retreat!' (Q18:16) and الغاون /al-ḡāwūn/ 'the deviators' (Q26:224). The pronunciation of داود دواد 'David' is difficult to determine, so it is not entirely certain whether that should be interpreted as an example of double $w \bar{a} w$ avoidance (see A.2.8).

Diem takes ancient sequence ${ }^{*} a \bar{u} \bar{u}(n a)$ of III-? stems in the plural as having developed to $/ \mathrm{aw} \overline{\mathrm{u}}(\mathrm{n}) /$. It seems likely however that III- $\mathrm{P}$ and III-w/y stems have merged completely and these should rather be read as /aw(n)/. From spellings such as يستهزون/yastahzūn/ > "yastahzi?üna it is clear that at least the "i?u sequence has merged completely with III-w/y stems. Indeed, in the reading traditions we see this with some of these verbs, with etymological -a? ūna forms, e.g. ?abū ĞaYfar's yațawna 'they step' < 'yața?ūna and murğawna 'postponed' probably < "murğåūna (see §6.5.5).

Diem likewise analyses the adjectives روف 'compassionate' and يوس 'despairing' as evidence of $a \bar{\imath} \bar{u}>a w \bar{u}$ being represented by a single $w \bar{a} w$. Once again one has to wonder whether this is a correct identification. For روف, Diem

15 I thank Ahmad Al-Jallad for suggesting this analysis to me.

16 إن تلو 'you distort' (Q4:135) is also read as talū by Ḥamzah and Ibn Yāmir (Ibn al-Ğazarī $\S 2962$ ), so may not represent an example of this. The interpretation of the reading talu seems somewhat controversial. Al-Farrā? (Maৎānī I, 291) derives it from a root lîy, which he claims has the same meaning as tatawallaw 'they follow in succession'. Ibn Xālawayh $($ Huğğah, 127) see it as a G-stem of the root wly. 
implicitly assumes that the Hafș reading ra?ü $f$ is the origin of the word represented, and thus reconstruct /rawūf/, however, all other Kufan readers read raiuf (Ibn al-Ğazarī, § 2731), which would presumably yield/rawuf/ or perhaps /rawf/ after the loss of the hamzah, where spelling with a single wāw would be expected. يوس is universally recited as ya?ūs, but ya?us is reported in Arabic lexicography (Lisān 4945c), thus likewise opening up the possibility of the reading /yawus/. If his assumption that these come from $\mathrm{CaCu} C$ adjectival patterns holds up, however, these may indeed be good examples of $w \bar{u}$ being spelled with a single wāw, assuming that * $a$ ? $\bar{u}$ did not yield /awwu/ rather than /awū/ in this position.

To this he adds several other probable examples of this orthographic prac-

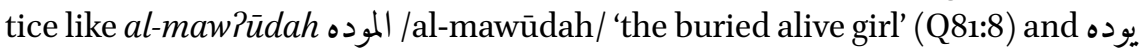
/yawūdu-h/ 'it tires him' (Q2:255). After the loss of hamzah روس 'heads' probably became /rūs/ (Q2:279) as the plural of /rās/ in analogy to /sāq/ pl. /sūq/ (incidentally also read as su?ūq, see §6.4.10), but /ruwūs/ cannot be excluded.

Like double $w \bar{a} w$, the sequence of double Palif is avoided. This is clearest in the case of nouns that end in ?alif mamdüdah, followed by an indefinite accusative. Rhyme confirms that such sequences where indeed pronounced with two syllables, e.g. انشا /inšāâā/ 'a creation' (Q56:35), yet they are spelled with only one ?alif.

This same avoidance is found with the question particle I/Ra-/. When it combines with words that start with / $\mathrm{Ra}-, \mathrm{Pi}-, \mathrm{Pu}-/$, it is generally spelled with just a single ?alif, e.g. انتم /Ra-Pantum/ (or /āntum/?) 'are you?' (Q2:140), الك /a-(w)unz) /Ra-(y)innaka/ 'are you?' (Q37:52), انزل/a-(w)unzila/ 'has it been revealed?' (Q38:8). Occasionally however, such sequences are spelled phonetically rather than morpho-phonemically, in which case a glide is written in the place of the word-initial vowel that followers the question particle, e.g. اينك /a-yinna-kum/ 'do you?' (Q6:19), اونبيك /Ra-wunabbī-kum/ 'shall I inform you?' (Q3:15). Both

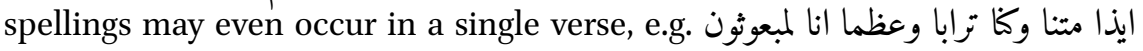
/a-yideā mutnā wa-kunnā turābā wa-Yizāāmā a-(y)innā (or innā) ${ }^{17}$ la-mabYūtūun/ 'When we die and become dust and bones, will we be resurrected' (Q56:47, cf. also the identical phrase in Q23:82 and Q37:16, where /a-(y)idā/ is spelled اذاذ).

\section{A.2.3 Palifal-Wiqāyah}

A place where the orthography of the QCT diverges rather sharply from Classical Arabic orthography is in its use of the so-called Palifal-wiqāyah. In Classical

17 There is significant disagreement among the readers whether to read these words with a question particle in front of both, for a discussed see Ibn al-Ǧazarī (§1413). 
Arabic, an Palif is written after word-final wāw only when this $w \bar{a} w$ denotes the verbal plural ending (Wright $1896, \S 7 \mathrm{a}$ ). In the QCT, its use is much more widespread, and regularly appears after any word-final / $\overline{\mathrm{u}} /$ or $/ \mathrm{aw} /$, regardless of whether it is the plural verb or not (Nöldeke et al. 2013, 418f.). This highly morphological spelling of Classical Arabic is thus an innovation. Examples of the broader use of the ?alif al-wiqāyah are, e.g. كفروا /kafarū/ 'they disbelieved' (passim), مشوا /mašaw/ 'they walked' (Q2:20), يدعوا /yadfū/ 'he calls'

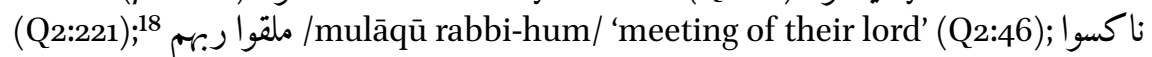
(وسمهم/nākisū rūsi-hum/ 'the hanging of their heads' (Q232:12). The relative pronoun /d̄ū/ which in the CE follows the Classical Spelling ذو, is consistently spelled ذوا in early Quranic manuscripts (Déroche 2009, 65).

There is only one case in the QCT where ?alif al-wiqāyah is not used for word-

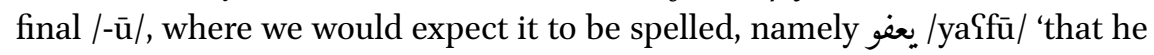
forgive' (Q4:99) (see B.3). An exception to the general rule that whenever wordfinal /-aw/ occurs it should be written with ?alif al-wiqāyah, are cases where a /w/ immediately precedes. Thus we find اوو /Rāwaw/ 'they gave shelter' (Q8:72, 74) and لو /lawwaw, lawaw/19 'they turn aside' (Q63:5). This orthographic practice is lost in the CE, but is consistent in early Quranic manuscripts (see B.4). There are two other words that end in /-aw/ words which in the CE are written without Palif al-wiqayah, one of them certainly had the Palif al-wiqayah in the UT, namely, سعوا /saSaw/ 'they strove' (Q34:5) and another whose data is a bit more ambiguous, as several very ancient manuscripts have the ?alif al-wiqāyah while (mostly) later ones lack it, namely: (I) عتو/ / / ataw/ 'and they became insolent' (Q25:21), see B.4.

Nöldeke et al. (2013, 418f.) object to the possibility that the Palif al-wiqāyah is intended to represent the phonetic value $/ \overline{\mathrm{u}} /$ and $/ \mathrm{aw} /$, and instead suggest that "every final $g$ is followed by an l" and "exceptions to the rule can be easily explained". However, one of the main exceptions is not addressed at all: All nouns that end in a consonantal $/ \mathrm{w} /$, either when preceded by a consonant, or when part of word-final / uww/ are consistently spelled without ?alif al-wiqāyah. Examples of word-final - $C w$ are: العفو/al-Cafw/ 'the surplus; the forgiveness' (Q2:219; Q7:199), باللغ /bi-l-lagiw/ (Q2:225; Q5:89; Q25:72), اللغ /al-lag்w/

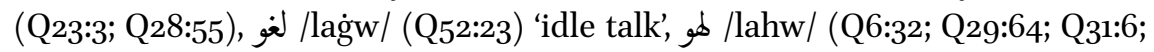
Q47:36; Q57:20), اللهو /al-lahw/ (Q62:11) 'amusement', البدو /al-badw/ 'the desert'

18 Thus, Quranic orthography is unable to make the distinction between the homophonous yad $\bar{u}$ 'he calls' and yad $\varsigma_{\bar{u}}$ 'they call (subjunctive/jussive)' which in Classical orthography is expressed as يدع versus يدعوا.

19 Ibn al-Ǧazarī (§4397) reports both variants lawaw (Nāfi and Rawḥ) and lawwaw (the rest). 
(12:100). Words that end in word-final -uww are: عدو / عaduww/ 'enemy' (Q2:36, and passim), العدو /al-Saduww/ 'the enemy' (Q63:4), بالغدو/ /bi-l-gंuduww/ 'in the mornings' (Q7:205; Q13:15; Q24:36), لعفو/la-Tafuww/ 'surely oft-pardoning' (Q22:6o; Q58:2), عتو / futuww/ 'arrogance' (Q67:21). The rule as formulated by Nöldeke et al. does not account for this, whereas the phonetic definition (which they object to): wāw+?alif al-wiqāyah denotes /ū/ or /aw/, does.

$\operatorname{Diem}(1979, \S 47)$ tries retain the orthographic rule formulated by Nöldeke et al. while taking these forms into account. The orthographic rule he formulates, however, is sufficiently complex that it would take a linguist to be able to spell correctly. He suggests that the ?alif al-wiqayyah is only used of the ?alif could not be mistaken for the indefinite accusative. This does a reasonable job at explaining lagiwun لغ (Q52:23) versus lagiwan I لغو6:25), although even this requires a rather complex process of the scribe of needing to work through counterfactual readings, in order to ensure the ?alif does not get written accidentally. But it becomes especially difficult to square with the fact that the definite form does not take the Palif al-wiqāyah either, e.g. al-lagiwi اللغو (Q23:3), a context where writing the ?alif al-wiqayah could never lead to a confusion with the indefinite accusative.

Moreover, Diem's rule is based on the mistaken assumption that lu?lu? 'pearl' distinguishes the indefinite accusative luPlupan لو لو from the other cases for lu?lu?un and lu?lu?in. This, however, is an idiosyncrasy of the CE. In the UT, this word always received the ?alif al-wiqayah also in the nominative and genitive form (see B.6).

Since indeed the use of Palif al-wiqāyah in these words is most readily explained phonetically, it being used whenever it is vocalic $/ \overline{\mathrm{u}} /$ or diphthon$\mathrm{gal} / \mathrm{aw} /$, whereas when it is consonantal it is spelled without, it seems to me that contrary to the popular belief, the ?alif al-wiqayyah does represent a phonetic value, rather than it being a purely orthographic practice (and certainly not a 'word-divider').

The reason why $/ \overline{\mathrm{u}} /$ and $/ \mathrm{aw} /$ are treated the same may be up for debate. First, it is of course possible that Quranic Arabic had lost final /aw/ of the verbs. In many modern dialects, e.g. Damascene Arabic, the final weak ending - aw has been lost completely and merged with $-\bar{u}$, e.g. katabu 'they wrote' and banu 'they built' not **bano (Cowell 1964, 55, 61). It is possible that these merged in Quranic Arabic although a more conservative reconstruction seems prudent.

Another point of comparison here is the treatment of diphthongs in the Old Arabic as reflected in the Safaitic inscriptional corpus. Safaitic orthography never writes vowels with matres lectionis. Thus, $/ \overline{\mathrm{u}} /$ is never expressed with $\langle w\rangle$. Perhaps surprisingly, the diphthong /aw/ is treated the same, and is likewise never expressed in writing whereas consonantal $/ \mathrm{w} /$ is expressed with 
$\langle w\rangle$. Thus, to the speakers of the Safaitic Old Arabic dialect, the diphthong /aw/ was treated as a true diphthong, that is more similar to a long vowel than a vowel+consonant sequence (Al-Jallad 2015, 37 f.).

The treatment of /aw/ and /ay/ as being distinct from other consonantal uses, and more akin to the long vowels, is also something we see in their treatment in the Arabic grammatical tradition. Thus, the hurüf al-linn are the use of Palif, $y \bar{a}$ ? and $w \bar{a} w$ when a vowel precedes, in words like: $n \bar{a} r$ 'fire' - envisioned as /naAr/, dār /daAr/ 'house', fïl / fiyl/ 'elephant', qüla /qiyla/ 'it is said', huüla /huwla/ 'it was changed' ḡül /guwl/ 'ogre', bayt 'house' and țawb 'garment' (Lisān, $4117 \mathrm{c}) .{ }^{20}$

In light of this it seems quite likely, and phonologically plausible that the Palif al-wiqāyah was used as a tool to write word-final 'vocalic' uses of $w \bar{a} w$, i.e. $/ \overline{\mathrm{u}} /$ and $/ \mathrm{aw} /$ as opposed to consonantal uses of $w \bar{a} w$.

Another argument that Nöldeke et al. bring up to not take this as a phonological spelling, but rather a 'place $w \bar{a} w$ after every $w \bar{a} w$ ' rule is that it is placed

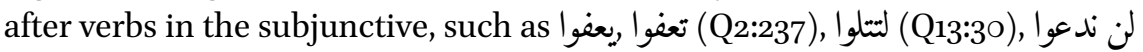

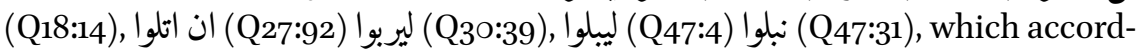
ing to them must be verbs ending in $-u w a$ not $-\bar{u}$. This presupposes that the Quranic reading traditions are an accurate representation of the language of the QCT, and final short vowels were not lost in such verbs. Neither of these assumptions are justified. The fact that these verbs are treated exactly the same as verbs that end in $-\bar{u}$ in Classical Arabic rather speaks in favour of the loss of the final short vowels, something that I have also argued on different grounds in Chapter 7 and Van Putten \& Stokes (2018).

An exceptionally difficult issue is the treatment of the Palif al-wiqāyah in roots that originally contained hamzah. While some of these behave exactly as expected, it is especially the historical sequences *-a?u and ${ }^{*} \bar{a} ? u$ that paint a rather complex picture. Nöldeke et al. $(2013,419)$ object to seeing the Palif alwiqāyah as a phonetic marking for $/ \overline{\mathrm{u}} /$ and $/ \mathrm{aw} /$ as against consonantal $/ \mathrm{w} /$, because many words of the type have final hamzah. This, again, presupposes that the Quranic reading traditions are an accurate reflection of the language of the QCT, which certainly in the case of the hamzah cannot be accepted. It is quite clear that Quranic Arabic had lost hamzah completely (see §5.2) which

$20 \quad$ Ibn al-Ğazarī ( $9948, \S 950, \S 1234, \S 1343)$ makes an explicit distinction between hurūf al-madd $(\bar{u}, \bar{\imath}, \bar{a})$ and harfay al-līn $(a w, a y)$. This does not appear to be a distinction systematically made by the early grammarians like Sībawayh, which seems to use the terms indiscriminately, and often uses the compound term hurüfal-madd wa-l-līn. Even if it were an ancient distinction, the two terms are still clearly distinguished from uses of $w \bar{a} w$ and $y \bar{a}$ ? were a consonant, rather than a vowel, precedes. 
has given rise to many forms of artifical and pseudocorrect hamzah use all throughout the reading traditions (see Chapter 6 and §3.6.1). In the following sections we will discuss the different contexts where ?alif al-wiqayah appears where the words etymologically contained a hamzah.

\section{A.2.3.1 Palif al-wiqāyah for Stem Final *u?}

When it comes to stem final * $u$ ?, regardless of what vowel would historically follow, the word is always spelled with Palif al-wiqāyah. Thus امروا /imrū/ 'man'

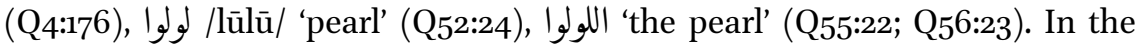
Cairo Edition some these forms of 'pearl' are spelled without ?alif al-wiqāyah, but this not original to the UT, see B.6.

In the case of the indefinite لولوا 'pearl', the spelling is thus ambiguous whether it represents nominative/genitive /lūlū/ or accusative /lūluwā/. This ambiguity has indeed lead to disagreement in the Quranic reading traditions where the word may be read both as a genitive lu?luPin, lülu?in and as an accusative lu?lu?an, lūlu?an (Q22:23; Q35:33, see Ibn al-Ğazarī, §3652).

\section{A.2.3.2 Treatment of Stem-Final *̄u?}

In nouns, etymological sequences of stem-final " $\bar{u}$ ? behave exactly the same as stem-final /uww/, and thus are spelled without Palif al-wiqāyah: قرو /quruww/ (< qurūp-) 'menstruations' (Q2:228) سو/suww/ (> *sūP-) 'the wickedness of ...' (Q2:49, and passim), بالسو 'wickedness' (Q2:169, and passim), السو 'wickedness' (Q4:17, and passim). Of course, in the indefinite accusatives, these receive a final Palif as the mark of the indefinite accusative, e.g. سوا /suwwā/ 'wickedness' (Q4:110)

In the verbal system, however, we find these spelled with Palif al-wiqāyah in the two instances that it occurs. What is recited in the reading tradition as la-

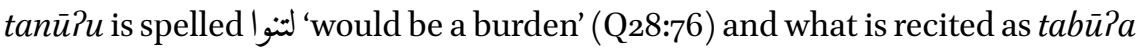
is spelled Ithat you bear' (Q5:29). This is likely the result of analogical leveling due to a partial paradigmatic levelling of the II- $w$, III- ? imperfect paradigm with the III- $w$ paradigm:

\begin{tabular}{|c|c|c|c|c|}
\hline & Proto-Arabic & & Hamzaless Arabic & \\
\hline & III-W & II-W, III-? & III-W & II-W, III-? \\
\hline 3sg.m. & *yastū & *yabū?u & yaSlū & *yabuww > y yabū \\
\hline 3pl.m. & ‘yaslū $(n a)$ & *yabu? $\bar{u}(n a)$ & yaßlü $(n)$ & $y a b \bar{u}(n)$ \\
\hline 3pl.f. & ‘yastūna & *yabu?na & yaßlūn & yaslūn \\
\hline
\end{tabular}


The merger of II- $w$, III- $?$ verbs with III- $w$ verbs towards ending in /- $\overline{\mathrm{u}}(\mathrm{n}) /$ may perhaps be visible in ليسو/li-yasū/ (Q17:7) which is variously read as li-yasū?ū'so that they will sadden', li-yasūîa 'so that he will sadden' and li-nasūia 'so that we will sadden' (Ibn al-Ǧazarī, §3447). If the majority reading yasū? $\bar{u}$ was indeed the grammatical form intended, then it seems that the Quranic Arabic pronunciation of this was /li-yasū/.

\section{A.2.3.3 Treatment of Word-Final *ā?}

Unlike Classical Arabic spelling, II-w/y, III-? verbs in the in the perfect 3pl.m. form are spelled without an Palif al-wiqāyah, e.g. وباو /bāw/ 'they returned' (Q2:61); فاو /fāw/ 'they returned' (Q2:226)," جاو /ḡāw/ 'they came' (Q3:184) and also راو /râw/ 'they saw'22 (Q2:166; Q7:149; Q10:54; Q12:35; Q19:75; Q28:64; Q34:33; Q37:14; Q40:84, 85; Q42:44; Q62:11; Q72:24). The last of these is spelled I ر in the Cairo Edition, but this is not original to the UT, see B.7. As wordfinal $/ \overline{\mathrm{u}} /$ is otherwise always spelled with Palif al-wiqāyah, this suggests that word-final * ${ }^{*} \bar{q} \bar{u}$ shifted to /āw/, rather than ${ }^{*} \bar{a} w \bar{u}$ as Diem (1979, §65) suggests.

Of exceptional status is اسوا 'they did evil' (Q30:10; Q53:31) which is universally recited as Pasā? $\bar{u}$ and thus we would rather expect the spelling ***اسو. But indeed, in early Quranic manuscripts, the spelling is as it is found in the Cairo edition (see B.16). This spelling thus seems to suggest a pronunciation / Rasaw/ rather than /Rasāw/. As this is the only C-stem perfect in the 3pl.m. of stems of this type, it is difficult to be sure about this analysis.

\section{A.2.3.4 Word-Final *a?ū}

Plural hamzated verbs that historically end in ${ }^{*} a ?-\bar{u}$ are likewise spelled with the Palif al-wiqāyah and are presumably pronounced /-aw/: تبروا /tabarraw/ 'they disown' (2:167), فادروا /fa-draw/ 'so avert!' (3:168), اقروا /iqraw/ 'recite!' (Q69:19), فاقروا /fa-qraw/ 'so recite!' (Q73:20).

One verb lacks the final Palif al-wiqāyah: تبوو /tabawwaw/ 'they settled' (Q59:9), thus showing similar behaviour as the verbs without an original *? that have /w/ before a final /-aw/, like اوو /Rāwaw/ 'they gave shelter' (Q8:72, 74) and /lawwaw, lawaw/ 'they turn aside' (Q63:5) discussed above.

21 It is worth appreciating how the QCT aptly distinguishes this word from 1 |fāwū/ < $f a$ ?wū 'so retreat!' (Q18:16), which would have been homographic had the Classical Arabic rule of the Palifal-wiqāyah been adhered to.

The Quranic Arabic perfect of 'to see' was /rā?/, not /råā/, see § 5.11 for a discussion. 


\section{A.2.3.5 Word-Final *a?u(n)}

As for *a?u sequences, verbs are overwhelmingly spelled with $w \bar{a} w$ and ?alif al-wiqayah, with a couple of exceptions where it is simply spelled with Palif, e.g. يبدوا /yabdaw/ 'he begins' (Q10:4, 34 (2×); Q27:64; Q30:11, 27), تفتوا /taftaw/ 'you will not cease' (Q12:85), يتفيو / اتوكوا I 'Ileatafayyaw/ 'it inclines' (Q16:48)

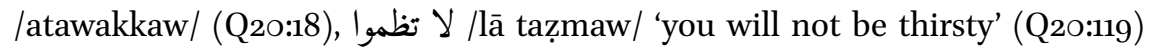
يدروا /yadraw/ 'he knows' (Q24:8), ما يعبوا /mā yaSbaw/ 'will not concern himself' (Q25:77), ينشوا /yunaššaw/ 'is brought up' (Q43:18), ينبوا /yunabbaw/ 'will be informed' (Q75:13). There are three exceptions to this general rule, namely يتهحزا / يستر /yustahzā/ 'it is being ridiculed' (Q4:140), يتبوا /yatabawwā/ 'he settles' (Q12:56), تنبوا Inatabawwā/ 'we settle' (Q39:74).

For nouns, the ?alif spelling is more common, although the spelling with ?alif al-wiqāyah occurs as well. Thus for *al-mala?u 'the chieftains' we see: /al-malā/ (Q7:6o 66, 75, 88, 90, 109, 127; Q11:27; Q12:43; Q23:33; Q28:38; Q38:6) and الملو /al-malaw/ (Q23:24; Q27:29, 32, 38). The other noun, from *naba?u 'the news of', on the other hand, occurs more often in the wāw + Palif al-wiqāyah spelling: نبوا /nabaw/ (Q14:9; Q38:21; Q64:5) but /nabā/ (Q9:70). The indefinite form “nabaiun 'news' is likewise spelled نبو (Q38:67) (see B.8, B.9).

The presence of these spelling with final wāw and Palif al-wiqāyah seems to have an important implication for the relative chronology of final short vowels and the hamzah, as it requires that hamzah was lost before the final short vowels were lost. The forms that are simply spelled with ?alif are perhaps analogical levelling of the default form, as verbs that end in $-\bar{a}$ do not usually show a distinction between the imperfective and aorist/apocopate, and likewise nouns that end in $-\bar{a}$ do not usually show a distinction between the nominative versus the accusative after the loss of final short vowels. ${ }^{23}$

\section{A.2.3.6 Word-Final *ā?u}

An especially vexing case of the issue of the ?alif al-wiqayah in words that etymologically end in ?alif mamdüdah followed by the nominative or imperfect * $u$. First of all, it should be said that unlike the reflexes of * $a$ ? $u$-where the distribution is almost $50 / 50$ - the vast majority of the words in this group are simply spelled with the final ?alif. However, there are 18 cases in the CE where a spelling with $w \bar{a} w+$ ?alif al-wiqa ay a h shows up. However, a closer look at the data in early Quranic manuscripts shows that not all of these can be successfully reconstructed with that spelling in the UT. B.10, B.11, B.12, B.13, and B.14 tabulate

23 The genitive seems to show similar free variation, but there is only evidence for it in construct e.g. نباى المرسلين (Q6:34) but من نبا موسى (Q28:3). 
the attestations of the relevant words as they appear in early manuscripts. Here I will give a summary of the conclusions we can draw from this examination. Below, I have also included a few cases where an unusual spelling occurs where the $\mathrm{CE}$ has ?alif.

\begin{tabular}{|c|c|c|c|}
\hline & Qirā?āt & $\mathbf{C E}$ & UT \\
\hline Q5:18 & Pabnā?u & ابنوا الله & ابنا الله \\
\hline Q6:5 & २ambāîu & أنبوا ما & انبوا ما \\
\hline$Q_{26} 6$ & २ambāîu & انبوا ما & انبا ما (probably) \\
\hline Q6:94 & šurakā?u & شركوا & شركا \\
\hline$Q_{42: 21}$ & šurakāîu & ركوا & شركوا \\
\hline Q30:13 & šufaৎāîu & شفعوا & شفعا \\
\hline Q14:21 & ad-duৎafã?u & الضعفوا & الضعفوا \\
\hline Q40:47 & aḍ-duৎafā?u & الضعفوا & الضعفوا \\
\hline Q35:28 & al-\{ulamā? & العلموا & العلموا \\
\hline Q26:197 & Sulamāîu & علموا بنى اسريل & علما بنى اسريل \\
\hline Q6o:4 & bura?ā?u & ل مبروا & ا مبرو \\
\hline Q11:87 & našāâu & ن نشوا & شُوا or شاو \\
\hline Q37:106 & al-balāîu & البلوا & البال \\
\hline$Q_{44: 33}$ & balā?un & بلوا & ب باx \\
\hline Q40:50 & $d u \varsigma \bar{a} ? u$ & دعوا الكفرين & دعا الكفرين \\
\hline Q5:29 & ğazā? & جزوا الظلمين & جزاو الظلمين \\
\hline Q5:33 & ğazā? & جزوا الذين & جزاو الذين \\
\hline Q20:76 & ğazā? & جزامن & جزاو من \\
\hline Q39:34 & ğazā?u & جز| المحسنين & جزاو المحسنين \\
\hline$Q_{42: 40}$ & ğazā?u & جزوا سييه & جزاو سييه \\
\hline Q59:17 & ğazā?u & جزوا الظلمين & جزا الظلمين \\
\hline
\end{tabular}

Of the 19 words spelled with the ?alif al-wiqāyah, only six appear to have been spelled as such in the UT, with one (نشوا Q11:87) being somewhat unclear. In

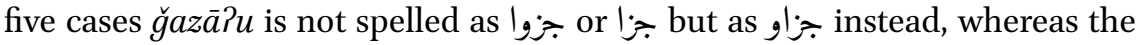
spelling جزوا is entirely absent. The normal spelling of Palif mamdüdah nouns with simple ?alif remains the majority spelling however (10 cases).

All cases of the $\mathrm{g}$ spelling are nouns in construct (a place where final short vowels appear to have been retained), and thus جزاو may very well represent /ğazāwu/, with optional weakening of stem final hamzah, whereas I ị in identical context would represent /ğazā?u/. With a clitic following, this noun is 
variously spelled with and without the final glide in the UT (A.4.11). This spelling would then align with the proposed theory here that $w \bar{a} w$ not followed by ?alif al-wiqāyah represent consonantal /w/. The only fly in the ointment is انبو (Q6:5) which is likewise stands in construct but has the ?alif al-wiqāyah. A possible solution is to not read this as a $? a C C \bar{a} C$ plural, but rather as a $? a C C u C$ plural,

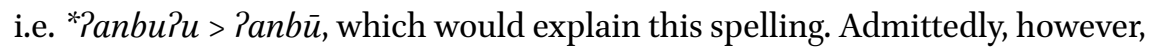
this solution is rather ad hoc.

The remaining words with the ?alifal-wiqāyah spelling are all diptotic CuCaCā?u plurals that do not stand in construct. Among these nouns, spellings of this type are fairly common with, five times appearing with the wāw+?alif alwiqayah in the nominative, and 19 cases where it is spelled with Palif. Rabin (1951, 110, §w) speculates (following Vollers) that these forms represent /addufafō/ with a final vowel $/ \overline{\mathbf{o}} /$, and he seems to think that there is no special relationship between this spelling and the nominative. The fact that we never see such spellings in non-nominative contexts (which are by no means uncommon) however make this rather unattractive to assume that the original case vowel plays no role here.

However, it is similarly unlikely to take these spelling as representing /āwu/, or even /ā?u/ (as suggested by Diem 1981, §184a; and Nöldeke et al. 2013, 422). In contexts much less ambiguous than the very specific context of $\mathrm{CuCaCa}$ ? $u$ plurals, it seems to be clear that with such a sequence the spelling gl would be expected, at least usually (see the reflexes of ${ }^{*} \bar{a} ? \bar{u}$, and $* \check{g} a z \bar{a} ? u$ above). I would tentatively suggest that for reasons currently not entirely clear, the outcome of diptotic ${ }^{*} \mathrm{CuCaCā}$ u indeed is $/ \mathrm{CuCaCō} /$, creating a diptotic case distinction not dissimilar to the sound masculine plural with $/ \mathrm{CuCaCo} /$ in the nominative and $/ \mathrm{CuCaCā} /$ / or /CuCaCā/?) in the oblique. Quranic Arabic then represents a stage where such nominatives have mostly, but not entirely, been analogically levelled.

The difference in behavior of the diptotic plurals may very well be because of their lack of nunation. Thus ${ }^{*}-\bar{a} ? u$, ${ }^{*} \bar{a}$ ? $a$ became $/-\overline{0}$, $-\bar{a} /$, because there was no

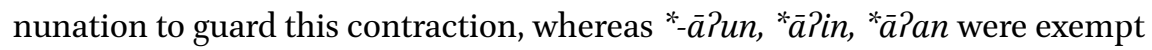
from this contraction and became /-ā?, -ā̂, -â̄?ā/. This may also explain why *Pawliyā $\bar{\imath} u$ - when followed by pronominal clitics appears to behave as ending in Palif maqșūrah /Rawliyā-hum/ rather than Palif mamdūdah **/Pawliyāwuhum/ (see A.4.11). Without further data this hypothesis will have to remain speculative.

\section{A.2.3.7 ربا ,الربوا}

A final word whose spelling appears to contain an Palif al-wiqāyah is الربو الربو 'usury' (Q2:275 (3×), 276, 278; Q3:130; Q4:161), which in the indefinite appears spelled 
as ربا (Q30:39) (see B.15). This alternation between I and I spelling may at first glance seem similar the treatment of the * $\mathrm{CuCaCa} ? u$ plurals discussed above. However, unlike the nouns above, this spelling is not unique to the nominative, but is found in all cases but the nominative, e.g. الذين يا كلون الربوا (those who devour usury (acc.)” (Q2:275), مثل الربوا "like usury (gen.)” (Q2:275).

It is quite unclear what the etymological background of this word is and how to interpret it. In the Quranic reading traditions it is either read as ar-riba or $a r$ ribē (Ibn al-Ğazarī, § 1974), but on the basis of the spelling with $w \bar{a} w$, it has been argued that it should be /ar-ribō/ (Rabin 1951, 105; Nöldeke et al. 2013, 418). As Rabin points out, this is an opinion, already endorsed by al-Zamaxšarī (Kaš$\check{s} \bar{a} f$, I, 319). However, there are no other stems with $/ \overline{\mathbf{o}} /$ as a word-final vowel, regardless of case-and there is no obvious etymological origin for this vowel to appear in this context. As shown by Van Putten (2017a), * $a w V$ - yields $/ \bar{a} /$ in Quranic Arabic, not / $\overline{\mathbf{o}} /$, and thus we would expect *ar-ribawa to have yielded **ar-ribā/, or perhaps even الربـ/ar-ribē/..24 Due to the unusual position of this word, Rabin $(1951,109, \S \mathrm{u})$ seems justified in assuming that the word is likely a borrowing of some kind, but the exact linguistic origin remains unclear.

\section{A.2.3.8 Summary}

The table below summarizes the distribution of the different spelling of ?alif alwiqāyah and $w \bar{a} w$ (as well as the spellings $\mathrm{g}$ and simply I). Excluded from this table are several highly frequent particles which are never spelled with ?alif al-wiqayah. These are absolute, I have shaded the cell with the dominant spelling.

\begin{tabular}{|c|c|c|c|c|c|c|c|c|c|c|}
\hline & ${ }^{*} \bar{u}, * u w a$ & ${ }^{*} u P v(n)$ & $* a w$ & ${ }^{*} a \bar{P}_{\bar{u}}$ & ${ }^{*} a ? u(n)$ & ${ }^{*} \bar{a} P u(n)$ & ${ }^{*} \bar{a} P \bar{u}$ & ${ }^{*} u w w v(n)$ & ${ }^{*} \bar{u} P(n)$ & ${ }^{*} \mathrm{Cwv}(\mathrm{n})$ \\
\hline وا & 3461 & $3(+2 ?)$ & 218 & 6 & 22 & $6(+1 ?)$ & 2 & & 2 & \\
\hline او - او & & & & & & $5(+1 ?)$ & 20 & & & \\
\hline و & 1 & & $3\left({ }^{*}\right.$-waw $)(+1 ?)$ & $1\left({ }^{*}\right.$-wa?̄ $)$ & & & & 31 & 47 & 16 \\
\hline 1 & & & & & 16 & 221 & & & & \\
\hline
\end{tabular}

24 Some Arab Grammarians appear to have argued that unlike *CaCaw- stems, like "stick", originally *CiCaw- and *CuCaw- stems shifted their final root consonant to $y$, something that also happened in Quranic Arabic الضخى /aḍ-ḍuhê/ 'the forenoon' (Q93:1) and العلى /al-Gulē/ 'highest (plural)' (Q20:4). For a brief discussion see Ibn al-Ǧazarī (§ 1974). 
It should be clear that the two spellings $\mid g$ and $g(\mid)$ are in quite strict complementary distribution, clearly suggesting a phonetic origin for these spellings. The only environment where such spellings appear to be in competition is in the ${ }^{*}-\bar{a} ? u(n)$ sequence. However, as we saw above even here the two spellings appear to be mostly in complementary distribution, where $و$ is reserved for triptotic nominative nouns in construct, and $\mathrm{g}$ is reserved for diptotic nouns in the nominative definite and indefinite form. It therefore seems quite reasonable to suggest that indeed $\mathrm{I}$ is used to write $/-\overline{\mathrm{u}} /$ and $/$-aw $/$, whereas g marks word-final consonantal /w/.

\section{A.2.4 Spelling of la- 'Indeed' as}

In the Quran the asseverative la-is frequently spelled $\downarrow$ before 1 sg. form of the verb. ${ }^{25}$ It is attested once in the CE in لا لاذبحنه /la-Padbahanna-h/ 'I will surely slaughter him' (Q27:21), but attested in quite a few more places in Early Quranic Manuscripts, for example فلا قطعن /fa-la-Puqațtịann/ 'So surely I will cut off' (Q20:71 in SM1a); لا الاكيدن/la-Pakīdann/ 'surely I will plan' (Q21:57 in W, T26); لا لاملن /la-Pamlānna/ 'I will surely fill' (Q32:13 in W, ${ }^{27} \mathrm{~T} ;{ }^{28} \mathrm{Q}_{38} 8: 85$ in BL); (wa-la-Pugiwiyanna-hum/ 'and surely I will mislead them' (Q15:39 in Arabe 334c); ولاامنهم /wa-la-Pāmuranna-hum/ 'I will surely command them' (Q4:119 in W, Arabe 33ob); ولا لادخلنك 'I will certainly admit you' (Q5:12 in Arabe 324c); 29 لا قتلنك /la-Paqtulanna-k/ 'I will surely kill you' (Q5:27 in W, ${ }^{30}$ CPP, BL ${ }^{31}$ ); لا لاتينه/ /la-Patiyanna-hum/ 'I will surely come to them' (Q7:17 in S, SM1a, K); لاصلبنك /la-Pușallibanna-kum/ 'I will surely crucify you' (Q7:124 in CPP, ${ }^{32}$ ); la-Pazīdanna-kum/ 'I will surely increase you' (Q14:7 K33); لا لا لازيدكنكم /la?uSadddibanna-hū/ 'I will surely punish him' (Q27:21 in W, T).

Besides these extra places in the Quran where we attest such spellings, there are also some disagreements among the reading traditions about whether certain phrases should be read with $l \bar{a}$ or asseverative $l a$ - that seem to stem from لو شا الله

25 Blau $(1967, \S 8.2)$ gives several clear examples of this same orthographic feature in early

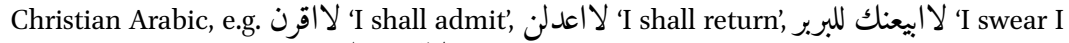
shall sell you to the Berbers', 'لاصنهاص 'I shall do it', etc.

26 The extra ?alif has been removed.

27 The extra ?alif has been removed.

28 The extra ?alif has been added by a later hand.

29 The extra ?alif has been removed.

30 The extra Palif has been added by a later hand.

31 The extra Palif has been added by a later hand.

32 The extra Palif has faded, and was perhaps removed on purpose.

33 The extra ?alif has been removed. 
Law šāâ بllāhu mā talawtu-hū Salaykumū wa-la-Padrā-kumū $b i-h \bar{\imath}$ "and if Allah had willed it he would have not have recited it to you, and he would have made it known to you" rather than reading ولادريك به as wa$l \bar{a}$ Padrā-kum bi-hī "nor would he have made it known to you" (Ibn al-Ğazarī, §3247). ${ }^{34}$ Qunbul San Ibn Kațīr also reads لا قسم بيوم القيمه (Q75:1) as la-iuqsimu bi-yawmi l-qiyāmah 'I definitely swear by the day of resurrection', while the rest reads lā ?uqsimu bi-yawmi l-qiyāmah 'No! I swear by the day of resurrection' (Ibn al-Ğazarī, § 3247$)^{35}$

Sidky $(2021,181)$ points out that it was already noticed early on that this surprising early orthography could yield significant ambiguities as both the asseverative and negative indicative would end up being spelled exactly the same, which al-Farrā? criticitices as being "of the terrible spelling practices of those of old" (wa-huwa min sūpi hiğā?i l-Pawwalīna) (Al-Farrā? Maৎānī, I, 295f.).

The spelling as $\downarrow$ is not just restricted to cases of the asseverative particle before a 1sg. verb, but can occur before any word that starts with a hamzah; AlDānī (MuqniS, 36) reports the spelling لاوضعو 'they were active' (Q9:47), which is indeed attested in early manuscripts (G K; B B; Rampur Raza). And likewise, for the asseverative particle combined with the preposition الى we find the spelling لاالى (Q3:158: S, W, ${ }^{36}$ Q47, GK, ${ }^{37}$ CPP; Q37:68: W, Arabe 333d), as pointed out by Diem (1979, § 26). A close examination of early manuscripts will likely uncover even more cases.

\section{A.2.5 The Prepositions Salā, hattā and ladā Are Often Spelled}

It is common in early copies of the Kufic $\mathrm{C}$ style to write the prepositions $\{a l \bar{a}$ and $h a t t a \bar{a}$ as حتا rather than the now standard على and and 2015, 208-213), manuscripts of this type appear to always be of Medinan regionality (Cellard 2015, 168-186; see also van Putten 2019a, see especially 356, note 122). This alternate spelling is also found once in the CE for ladā: لدى (Q40:18) and I I (Q12:25). These three words are exactly the words with Palif maqșürah that reading traditions that have III-w Pimālah (see §3.3.3.3) normally read as $/ \bar{a} /$, despite their spelling (Ibn al-Ğazarī, § 1973), ${ }^{38}$ and ḥattā is explicitly mentioned

34 Surprisingly, this reading is not mentioned by Ibn Muğāhid (121), despite Qunbul being his direct teacher.

35 Most works mention explicitly that Q75:2 ولا اقسم بالنفس اللوامه is read as wa-lā Puqsimu bi-n-nafsi l-lawāmah 'And nay! I swear by the reproaching soul' even by Qunbul, although here too a reading wa-la-?uqsimu seems more natural.

$36 \quad$ The Palif has been removed.

37 The Palif has been removed.

38 Also, the preposition الى is read as /Rilā/ rather /Rilē/, but this word is not commonly spelled الا (but see the corrected spelling of الى الى Q46:5 in CA1). 
as being an exception by Sibawayh (IV, 135). It seems to be the case that these words in Quranic Arabic were probably pronounced /hattā/, / Yalā/ and /ladā/, despite their spelling. The spelling with $\checkmark$ for these words should probably be considered historical spellings, rather than reflecting the pronunciation of Quranic Arabic (van Putten 2017a, 62). ${ }^{39}$

The most likely explanation for this exceptional spelling of /ā/ with $\checkmark$ can probably be explained through their respective etymologies. It seems likely that in the history of Quranic Arabic these prepositions were *Pilay, *Falay, *laday, and *hattay..$^{40}$ When these would be combined with a noun starting with the definite article, it would create a *aya triphthong which would then contract to *e- and get subsequently shortened to $a$ in a closed syllable, e.g. *Calay al-rağuli $>$ *Gale l-rağuli > Sala l-rağul. From this realization Sala before definite articles, one could easily get a preposition Salā through backformation.

\section{A.2.6 Words Starting with /l/ Preceded by the Definite Article.}

The definite article when it precedes a word that starts with $J$, is sometimes written with only a single lām. This is regular for اليل 'night', and was probably original for الولو 'the pearls', which is written with only a single läm in two rather early manuscripts (see B.6). All forms of the relative pronoun in the Quran are spelled with a single lām, rather than the Classical Arabic practice which only maintains this spelling for the singular and masculine plural forms, whereas all other forms write it with two läms (see A.4.5).

The vast majority of the words whose stem starts with lamm however, are written with two lāms, most notably, of course, له /allāh/. The fact that even before the lamm the definite article is usually spelled morphologically rather than phonetically (unlike Nabataean Arabic) was one of the reasons for Van Putten $(2019 \mathrm{~b}, 15)$ to suggest that the definite article was probably assimilated in Quranic Arabic, as it is in Classical Arabic, and that at the very least it cannot tell us that it was unassimilated as it is in the Damascus Psalm fragment.

\section{A.2.7 Historical Hamzah Spelling with}

Šay? 'thing', in early Quranic manuscripts, is written both شاى شیى and apparently haphazardly but with a clear preference to spelling it with ?alif. In the

39 Such spellings also occur in the early papyri (Hopkins 1984, §10d, only mentioning حتا) and Christian Arabic (Blau 1967, §10.1). Considering the special position of these prepositions in the reading traditions and the grammarians, the spelling of these prepositions cannot be used as evidence that the vowel /ē/ and /ā/ have merged (pace Hopkins 1984, §12c; Blau 2002, §16).

On the etymology of hattā, see Al-Jallad (2017b). 
Cairo edition لشاى is attested in Q18:23. There is no special significance to this position in early manuscripts, where the spelling may occur elsewhere, and some manuscripts spell it لشى in Q18:23 as well (e.g. SM1a).41 I side with Diem $(1980, \S 127-128)$ that this is likely a historical spelling. There are many cases where an original *? next to a $* y$ or in a position where it would become a $y$ is spelled with the orthographic l. Other cases of this found in the Cairo edition are:

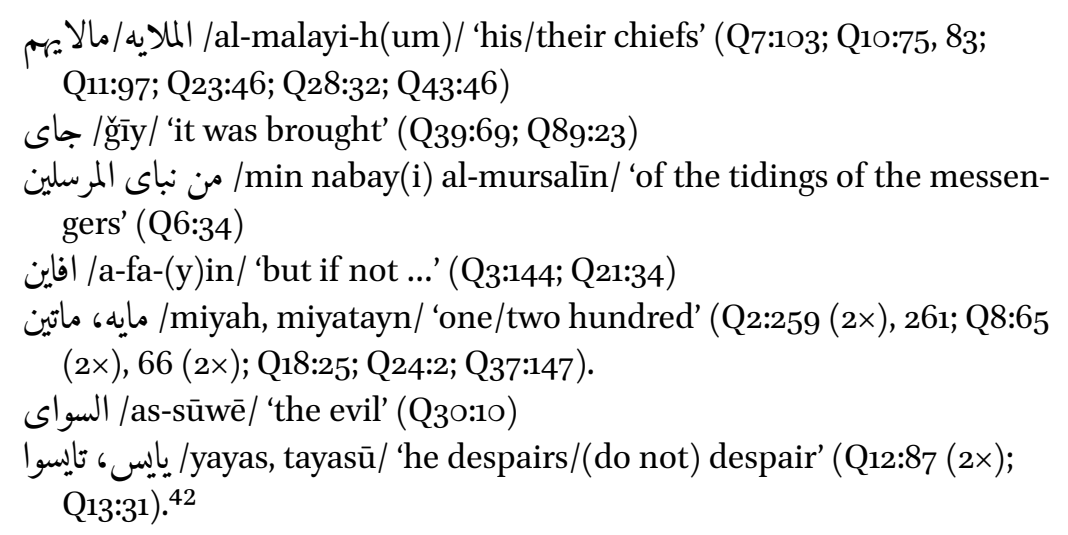

In early Quranic manuscripts, the verb شا 'to want' and 'to come' in the suffix conjugation also occasionally employs this spelling:

$$
\begin{aligned}
& \text { شايت 'you want' (sM1a, Q18:77; T, Q24:62) شاتخ 'you (pl.) want' (Arabe 331, } \\
& \text { Q2:223; DAM 01-21.3, Q7:161). جايت 'you came' (T, Q19:27) }
\end{aligned}
$$

Several other examples have been identified by Puin $(2011,164)$.

$$
\begin{aligned}
& \text { سايل /sīl/ 'it was asked' (Q2:108, in S, DAM o1-28.1) } \\
& \text { سايل /sìy / 'he was distressed' (Q11:77, in S) }
\end{aligned}
$$

\footnotetext{
41 The spelling شاى is also well-attested in the early Islamic Papyri (Hopkins 1984, §15d).

42 Diem (1980, § 127) explores the possibility that this might in fact represent/yāyas/, the outcome of the metathesized root Payisa 'to despair' as attested in several modern dialects, as well as in the Classical Arabic lexicons. He suggests this is not likely, as the perfect form does not point to this metathesis. I tentatively follow this conclusion, although it could be that $y$ ? > ? y was a regular metathesis, which eventually gave rise to the perfect stem being analogically remodeled towards ?ayisa. This other reading with metathesis is possible, and is in fact attested among the reading traditions, al-Bazzī Can Ibn Katīir reads istāyasū (Q12:80), tāyasū, yāyasu (Q12:87), istāyasa (Q12:110), yāyas (Q13:31), (Ibn al-Ğazarī $\S 1528)$. The metathesized perfect form of this verb is attested in the early Islamic papyri (Hopkins 1984, §56).
} 
إيايي/rūyā-y/ 'my vision' (Q12:10o in CPP; W; SM1a; Q12:43 in W, SM1a, GK) / bayyis/ 'wretched' (Q7:165 in A6140a ${ }^{43}$ )

An apparent application of this same spelling practice is found in the spelling of classical as-sayyi3ah. While this is spelled السييه in the CE, occasionally in early manuscripts we find الساييه, with the etymological Palif seemingly before the wrong consonant in terms of the seat of the hamzah.

$$
\text { Q7:95 الساييه /as-sayyiyah/ (CPP; BL) }
$$

A similar process is found on word-boundaries. Whenever a word is preceded by $b i$ - or $l i$ - and the consonant after the ?alif is a $y \bar{a} ?$, a second $y \bar{a}$ ? is written. In the CE this only occurs three times بايي /bi-(y)āyyām/ in the days of ...' (Q14:5), باييد /bi-(y)ayd/ 'with strength' (Q51:47), باييكم/bi-(y)ayyi-kum/ 'which of you' (Q68:6). But this practice is much more widespread in early Quranic manuscripts than it is in the CE. The spelling is especially common in the phrase بييت بwith the signs/verses of ...' which is subjected to a rigorous study by Déroche $(2014,47)$. Also, the singular باييه 'with the sign/verse of ...' is usually spelled in this manner. There are, at least, occasionally cases where the same spelling is employed after the prefix li- (van Putten 2018, $111)$.

bi-Payyi is invariably spelled as بائى in early manuscripts, as can be easily seen in the oft-repeated فبائin Q55 (see Arabe 331, W, sM1a, Top etc.). In other places in the Quran, we likewise find the same spelling regularly: فبائى (Q7:185; Q45:6; Q53:55; Q77:50), بائ (Q31:34; Q81:9) and لائي (Q77:12).

Van Putten (2018, 109f.) suggested that these spellings are hybrid spellings that represent both the original etymological ?alif, but use the $y \bar{a}$ ? to point out that these forms were now pronounced as /bi-yāyāt/, /bi-yayyi/ etc. Some evidence for this reading is furthermore found in the Quranic reading traditions. Al-Paṣbahānī Yan Warš Yan Nāfí is said to have pronounced every instance of fa-bi-Payyi as [fabiyayyi], and there is some disagreement within his transmission whether bi-Payyi-kum (Q68:6) and bi-Payyi (Q31:34) are read this way (Ibn al-Ğazarī, §1492-1493). There is however no mention of Q81:9, nor li-Payyi Q77:12, and nothing on bi-Pāāàt, bi-Paydin or bi-Payyām.

While Van Putten (2018) does not comment on this, it is very striking that whenever such a spelling takes place across word boundaries, it invariably

43 It is possible that the original reading of this word was rather /bāyis/, something both بايس and the more generally attested بيس also supports as a reading. There does not seem to be a significantly difference in meaning between $b \bar{a}$ ?is and ba?īs. 
involves a word that starts with I and has $\mathrm{s}$ later in the word. This is unlikely to be a coincidence. Perhaps the loss of word-initial *? did not undergo the same developments as word-internal *? (something suggested by other parts of its orthographic behaviour as well) and a secondary sound-law takes place where ${ }^{*} ?>y / i \_\breve{a} y$. The rather specific context in which the sound law takes place, however, is ad hoc and another solution may be thought of, but it seems that any explanation must account for the fact that this spelling practice seems to be conditioned by a $y$ later in the word. ${ }^{44}$

\section{A.2.8 The Spelling of dāwūd as and rưūs as رواد}

A rather puzzling spelling practice which may be related to the marking of historical hamzah when it stands next to $\bar{u}$ can be found in the name $d \bar{a} w \bar{u} d$. In the CE this name is spelled داود, but in early manuscripts it is frequently spelled دواد (Marx and Jocham 2015, 29ff.). It seems possible that this reversed order of the ?alif and $w \bar{a} w$ represents an alternative pronunciation of the name: /duwād/ or /du?ād/,45 similar to the appearance of the spelling ابرهيم and ابرهم for Pibrāhām and Pibrāhìm (van Putten 202ob). Unlike the spellings of ابرهيم إرهم no clear pattern arises of the two spellings being used in fixed places across manuscripts. In general, manuscripts either have the دواود or spelling (see B.17).

Such an explanation is less obvious for the representation of ruPüs however. It likewise occurs spelled as رواسهم in two manuscripts (Q14:43, Is. 1615 I, CA1). Here we can hardly argue that the pronunciation was ruwās or ru?ās. It seems then that, for whatever reason the 1 g sequence may reflect a historical sequence $* ? \bar{u}$, with the etymological position of the *? transposed, perhaps because it was ای no longer pronounced, much like what we saw with the historical spelling for words that involved $y \bar{a}$ ?, where the ?alif also often does not stand in the

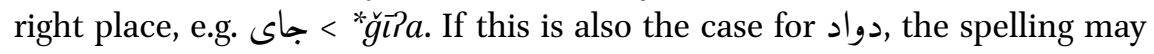
still represent /dāwūd/, which would then have come from an earlier *dā?ū ${ }^{4}{ }^{4}$ Note however, other manuscripts occasionally attest an etymological hamzah spelling for words with similar syllable structure, where the ?alif does stand in

44 This spelling convention on word-boundaries is not reported on for non-Quranic early Islamic Arabic, but it is at least found on the Dome of the Rock inscription which spells as باييات (dotted as such!) (Kessler 1970, 6).

45 Cf. the MuYtazilī Paḥmad b. Pabī Dưād (d. 24OAH), see EI²: s.v. Aḥmad b. Abī Du’ād. Of course, we may also entertain the idea that this is a later spelling pronunciation and in fact Ibn Pabī Dā?ūd was intended.

46 Which in turn could, in fact, come from *dāwūd again, due to the presence of a shift of " $w u$ and $w \bar{u}$ to $? u / \imath \bar{u}$ well-attested in Classical Arabic, and also found in the QCT once (see A.3.11). 
the etymologically correct position, e.g. باوسكاو (Q5:6, ms.or.fol. 4313), likewise yaîusan is spelled with a historical spelling ياوسا (Q17:83, Or. 2165) (see B.18).

\section{A.2.9 Plene Spelling of Short u}

Occasionally, the Quran attests examples where what was likely short $u$ is spelled with a $g$. This is well attested in forms of the plural demonstrative element *?ul- such as اوليك /ulāyik/ 'those', اولا /ulā?/ 'those'; اولوا /un/ 'those of (masculine, nominative)'; اولى /ulī/ 'those of (masculine, genitive/accusative)'; اولات /ulāt/ 'those of (feminine)'. For words of this type, this spelling practice continues to be the regular spelling all throughout the written history of Arabic. ${ }^{47}$ As it is unusual to find short vowels being spelled with a long vowel sign in the QCT, as this is not at all the norm, one might consider the possibility that these forms in Quranic Arabic originally had long vowels, as per their spelling. This option appears to be supported by Rabin $(1951,153)$, who however does not comment on it explicitly and also says that Classical Arabic has Püläri, which to my knowledge only occurs with a short vowel (Fischer 2002, §7, n. 7). However, the short vowel is in better agreement with the cognates of this plural morpheme in other Semitic languages, which all universally point to a short vowel. The spelling of short $u$ with $g$ is attested once in a context other than the plural pronoun base ?ul-, namely, ساوريك /sa-urī-kum/ 'I will show you' (Q7:145; Q21:37).

\section{A.2.10 Defective Spelling of Word-Final Long Vowels before Palif al-wașl}

While long vowels before ?alif al-waṣl are generally spelled plene, it appears that these long vowels were shortened, at least, before the ?alif al-wașl of the definite article, and this shortening is on occasion expressed in the orthography, as pointed out by Nöldeke et al. (2013, 409).

The vocative Payyuhā is usually spelled ايها in the QCT, but a spelling occasionally occurs. In all cases this happens in front of a noun with the definite

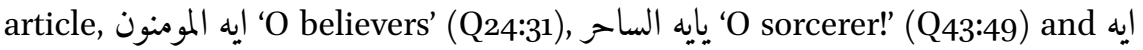
'O two dependents' (Q55:31). ${ }^{48}$ To my knowledge no other cases of defective final $\bar{a}$.

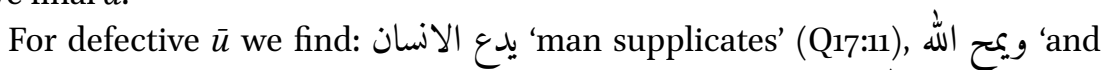

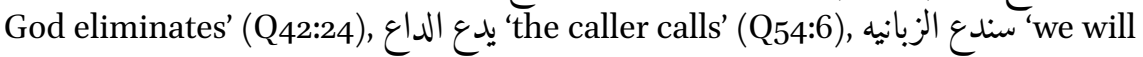
call the angels of Hell' (Q96:18), صلح المومنين 'the righteous ones of the believers' (Q66:4).

47 Puin $(2011,150)$ identified several early Quranic manuscripts where words of this type are occasionally spelled without the g, e.g. فاليك /fa-ulāyik/, الى /ulī/.

48 Cf. early Christian Arabic with the same practice (Blau 1967, § 9.2). 
Most common, however, is the shortening of $\bar{\imath}$ before Palif al-wașl: سوف يوت الله 'God will bring' (Q4:146), نبج المومنين 'we save the believers' (Q10:103), بالواد المقدس 'in the sacred valley' (Q20:12; Q79:16), لهاد 'verily a guide of those who' (Q22:54), واد النماد النمل 'God has given

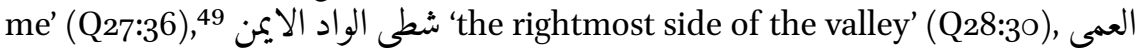
هد 'guide of the blind' (Q30:53), يردن الرحمن 'The beneficent intends for me' (Q36:23), صال الجيحيم 'the burning one in hell' (Q37:163), يعباد الذين 'O my slaves who

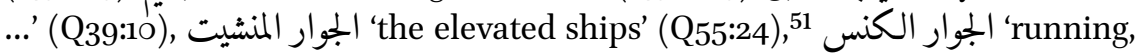
disappearing' (Q81:16).

A special case is يقص الحت (Q6:57) which is variously read as yaqdi l-haqq and yaqușșu l-haqq (Ibn al-Ğazarī, § 3029). Only in the former option are we dealing with the shortening of $\bar{\imath}$ before Palif al-wașl. However, I agree with Sadeghi (2013) that the second reading is probably original.

\section{A.3 Phonology}

\section{A.3.1 Consonants}

The consonantal system as can be reconstructed for Quranic Arabic based on the QCT has been illustrated in Van Putten (2019b). The table below reproduces the reconstructed phonological system, when the sign used in the transcription does not correspond to the IPA realization, the IPA realization is written behind it. In some cases, I have simplified technically ambiguous realizations of sounds to the most likely realization based on modern tağwìd realizations. For a more detailed discussion of other likely realizations, I refer the reader to Van Putten (2019b).

The ' sign, which usually marks 'unaspirated' is here to be understood as the glottis standing in prephonation state, i.e. a somewhat closed glottis which stops strong turbulent airflow (which leads to aspiration in stops and "voicelessness" in fricatives). For the stops this auditorily presents itself as unaspirated stops, and for the $s$ which is likewise mağhür, as a fricative without turbulent airflow (van Putten 2019b, 7-12).

49 See Van Putten (forthcoming) for a discussion on the spelling of this word and other cases of ?alif maqșürah followed by the clitic -ni/nì.

$5^{\circ} \quad$ Read by Ḥamzah as tahdi l- 'umya (Ibn al-Ǧazarī: § 3896 ).

$5^{1}$ المنشات in the CE, but this is an idiosyncrasy of this edition. See A.4.10 for a discussion on the spelling of this adjective. 


\begin{tabular}{|c|c|c|c|c|c|c|}
\hline & Labial & Dental & Lateral & Palatal/Dorsal & Pharyngeal & Glottal \\
\hline Stop & $b$ & $t\left[\mathrm{t}^{\mathrm{h}}\right], d, t\left[\mathrm{t}^{\mathrm{s}}\right]$ & & $k\left[\mathrm{k}^{\mathrm{h}}\right], \check{g}[\mathrm{f}], q\left[\mathrm{q}^{=}\right]$ & & $(?)$ \\
\hline Fricative & $f$ & $\underline{t}[\theta], \underline{d}[\partial], z\left[\partial^{\varsigma}\right]$ & $\left.d b^{\varsigma}\right]$ & $x[\chi], \dot{g}[\mathbf{\mathrm { s }}]$ & $h[\hbar], \mathcal{S}$ & \\
\hline Sibilant & & $s, z, s\left[\mathrm{~s}^{\varsigma=}\right]$ & & $\check{s}\left[\int\right]$ & & \\
\hline Nasal & $m$ & $n$ & & & & \\
\hline Approximant & & $r$ & $l$ & $y[\mathrm{j}], w$ & & \\
\hline
\end{tabular}

\section{A.3.2 The Loss of the Hamzah}

As has long been recognized, the orthography of the Quran seems to reflect a dialect that has lost the hamzah in most environments. In an earlier article, I have shown that rhyme confirms that this is not purely an orthographic idiosyncrasy, but is an accurate reflection of how the Quran was pronounced (van Putten 2018). ${ }^{2}$ The table below illustrates the main phonological developments caused by the loss of hamzah, along with examples.

Development

Example

${ }^{*} \mathrm{CPv}>\mathrm{Cv}$

*yasialu > يسل /yasal/ (Q70:10)

*al-Pafiidati > الافـ /al-afidah/ (Q104:7)

*ğuz?un > ج / ğuz/ (Q15:44)

${ }^{*} \mathrm{vPC}>\overline{\mathrm{v}} \mathrm{C}$

*ya?kulu > ياكل/yākul/ (Q10:24)

*yu?minu > يومن /yūmin/ (Q2:232)

*ad-dirbu > الذيب /ad-dīib/ (Q12:13)

${ }^{*} \mathrm{UP}>\mathrm{i} / \mathrm{uWW}$

*barî̉un > بري /bariyy/ or /barī/53 (Q6:19)

*sūiun > سو > سو / suww/ (Q3:174)

Final *ā? remains unchanged

*as-samā?i > السما /as-samā?/ (Q14:24)

*Pinšā?an > انشا /inšā?ā/ (Q56:35)

*aPa $>\overline{\mathbf{a}}$

*sa?ala > سال /sāl/ (Q70:1)

*a?i/u $>$ aWi/u?

*barisa > بيس /bayis/ (Q11:99)

*naqraiu-hū > نقروه /naqrawu-h/ (Q17:93)

*i/uPă $>$ i/uWā

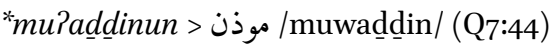

*firatun > فيه /fiyah/ (Q3:13)

$5^{2}$ On the topic of the hamzah spelling see also Diem (1976; 1980, §116-128).

53 See A.3.9. 
(cont.)

\begin{tabular}{|c|c|}
\hline Development & Example \\
\hline${ }^{*} \mathbf{i} / \mathbf{u} \mathbf{P} \mathbf{U}>\mathbf{U}$ & $\begin{array}{l}\text { *mustahzi?ūn > مستهزون /mustahzūn/ (Q2:14) } \\
\text { *al-mustahzi?īna > المستهزين /al-mustahzīn/ (Q15:95) } \\
\text { *ruPūsakum > روسك /rūsakum/ (Q2:196) }\end{array}$ \\
\hline *a?U > aW & $\begin{array}{l}\text { *yațaPūna > يطون /yațawn/ (Q9:120) } \\
\text { *barīsin > بيس/bays/54 (Q7:165) }\end{array}$ \\
\hline${ }^{*} \overline{\mathbf{a}} \mathbf{P} \mathbf{i} / \mathbf{u}>\overline{\mathbf{a} W i} / \mathbf{u}$ & $\begin{array}{l}\text { *sāPilun > سايل / دعايل (Q25ilyil/ (Q70:1) } \\
\text { *duYāiu-kum > (Q25:77) }\end{array}$ \\
\hline
\end{tabular}

\section{A.3.3 Vowels}

As for the vowel system of Quranic Arabic, it shares with Classical Arabic the short vowel system $a, i, u$ and likewise shares the long vowels $\bar{a}, \bar{\imath}$ and $\bar{u}$. However, the Classical Arabic $\bar{a}$ corresponds to $\bar{a}, \bar{e}$ and $\bar{o}$. The table below represents the phonemic system of Quranic Arabic that can be reconstructed from the QCT.

\begin{tabular}{lllllll}
\hline & Front & & Central & & \multicolumn{2}{c}{ Back/Rounded } \\
\hline High & $i$ & $\bar{\imath}$ & & & $u$ & $\bar{u}$ \\
Mid & & $\bar{e}$ & & & & $\bar{o}$ \\
Low & & & $a$ & $\bar{a}$ & & \\
\hline
\end{tabular}

Besides the Classical Arabic long vowels $/ \overline{\mathrm{a}} /, / \overline{\mathrm{l}} /$ and $/ \overline{\mathrm{u}} /$, Quranic Arabic had a fourth phonemic vowel which was written with a $y \bar{a}$ ? and likely pronounced as /ē/, e.g. هد /hadē/ 'he guided' (passim). It is clear from the rhyme that this was a separate sound from final /ā/ written with ?alif, $\S 5.8$, as they do not cross-rhyme. This fourth vowel /ē/ should not be seen as a variant of $\bar{a}$, which

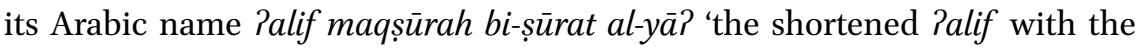
shape of the $y \bar{a}$ ?' $^{\prime}$ might suggest, nor should its pronunciation Pimālat al-?alif

54 This is the reading of Ibn Šihāb al-Zuhrī (Ibn Xālawayh muxtaṣar, 47). Some other possible interpretations of this rasm, e.g. /bayyis/ seems possible too. For a discussion see A.2.2. 
nahw al-y $\bar{a}$ ? 'The leaning of $\bar{a}$ in the direction of $\bar{\imath}$ ' be understood as a historical process, which was not the concern of the Arab grammarians. Instead, these are purely descriptive terms. Van Putten (2017a) has shown that not only is the Palif maqșūrah bi-șūrat al-yā? in the Quran pronounced differently, it also has a different historical background from the Palif maqșürah bi-șürat al-Palif and is fully phonemic so that it cannot be understood as an allophone. The table below gives an overview of some of the instances of Quranic Arabic /ē/ and the etymological origins from which it develops. It likewise shows that the outcome of the original triphthongs containing * $y$ is orthographically distinct from those that contain ${ }^{*} w$ and original ${ }^{*} \bar{a} .55$

\begin{tabular}{|c|c|c|c|c|}
\hline QCT & Quranic Arabic & Proto-Arabic & Classical Arabic & Gloss \\
\hline هدى & /hadē/ & *hadaya & هَدَى & 'he guided' \\
\hline ذكرى & $\begin{array}{l}\text { /hudēe/ } \\
\text { / } \text { dikrēē/ }\end{array}$ & $\begin{array}{l}\text { *hudayun } \\
\text { *dikrayu }\end{array}$ & 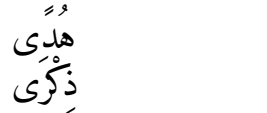 & $\begin{array}{l}\text { 'guidance' } \\
\text { 'a reminder' }\end{array}$ \\
\hline هديه & /hadē-h/ & *hadaya-hu & هَدَاهُ & 'he led him' \\
\hline تقيه & /tuqēh/ & *tuqayata & تَقِاةً & 'a precaution' \\
\hline دعا & /daYā/ & *daรawa & دَدًَا & 'he invoked' \\
\hline دعاه & /daYā-h/ & *daSawa-hu & دَعَاه & 'he called him' \\
\hline
\end{tabular}

Verbs with final /ē/ in early Quranic manuscripts, dissimilate to /ā/, written as Lor defectively when the pronominal suffix -nī/-ni follows (ن ن development happens when the 1sg. suffix -ya (ى) follows a noun that ends in $/ \overline{\mathrm{e}} /$. Van Putten (forthcoming) has argued that, since this spelling difference is phonetically conditioned, we are likely dealing with a regular dissimilation of $\bar{e}$ to $\bar{a}$ in the vicinity of $\bar{l}$ or $y$. This difference in spelling has mostly been lost in the $\mathrm{CE}$, where these verbs and nouns are treated exactly the same before the

55 The Cairo Editions contain a few exceptions to this orthographic practice. For example, iğtabā-hu (Q16:121) is spelled جتبه جتبه (Early Quranic manuscripts, however consistently spell this اجتبيه (e.g. B, W, BL, SM). The same is true for the same word in Q68:50 (e.g. W, SM). Likewise, Suqbā-hā (Q91:15) spelled عقبه in the Cairo Edition, is simply found as عقبيه in early manuscripts (e.g. SM, G) (see B.27). However, while مضىى /maḍē/ 'departed' (Q43:8) has the expected spelling in the $\mathrm{CE}$, early Quranic manuscripts surprisingly seem to converge on the spelling sis (see B.28). 
1sg. suffixes as before any of the other pronominal suffixes. For a full overview see Van Putten (forthcoming) but, one finds for example Q7:143: ترانى (W; sM1a; GK; BL; CPP; 33Og; DAM29 ترنى) where the CE has ترينى.

A small group of nouns in Quranic Arabic are written with a final gو. These are صلوه 'prayer' (passim), زكوه 'alms' (passim), حيوه 'life' (passim), منوه 'Manāt' (Q53:20), بالغدوه 'in the morning' (Q6:52; Q18:28); النجوه 'the salvation' (Q40:41) and كشكوه 'like a niche' (Q24:35). While these words are often explained as representing an orthographic innovative way of writing word-internal $/ \bar{a} /$, based on Aramaic spellings of some of these words, Al-Jallad (2017c) shows that this explanation is not very convincing. It is clear that all the words of Arabic origin in this list originally had a sequence *awat which monophthongized to /-ōh/ (see also §5.3).

Another word that may have had the phoneme / /0̄/ is الربوا /ar-ribō/ 'usury' (Q2:275 (3×), 276, 278; Q3:130; Q4:161). The spelling with wāw ?alif while in Classical Arabic ending up as $\bar{a}$, similar to the /ō/ of /șalōh/ becoming șalāh, șalāt may suggest that this word was /ar-ribō/. The etymology of this word is rather unclear (Rabin 1951, 109, §v), and current accounts of the phoneme $/ \overline{0} /$ do not predict native words to have $/ \overline{0} /$ in word-final position (Al-Jallad 2017c; van Putten 2017a). There is also no forthcoming explanation why the indefinite form of this noun apparently shifts this $/ \overline{\mathbf{o}} /$ to $/ \overline{\mathbf{a}} /$, as it is spelled ربا (Q30:39). Some nouns that etymologically end in a stem *-â? may have shifted to ${ }^{*}-\bar{a} \hat{\imath} u$ to $/ \overline{0} /$ in the nominative, as is discussed in more detail in A.4.11.

\section{A.3.4 Loss of Final Short Vowels and tanwin}

From the internal rhyme found in the Quran, it seems clear that what are considered the pausal pronunciations of final short vowels and tanwin are in fact also the pronunciation in verse internal position as well (van Putten and Stokes 2018). Hence the developments that have taken place are the following, ${ }^{*} u,{ }^{*} i,{ }^{*} a$, * $u$ and ${ }^{*}$ in are lost word-finally, whereas ${ }^{*} a n$ has shifted to $\bar{a}$. Case and mood vowels appear to have been retained in construct, however. This reconstruction seems to be further confirmed by the Quranic orthography which indeed lacks any sign of regular tanwin that we would have otherwise expected.

While throughout most of the corpus the generalization of this reduced case/mood system is borne out, there are a couple of Sürahs that appear to tell a different story, at least in pausal position. In several final short * $a$ appears to have been lengthened. In some cases, this appears in the QCT, and is further confirmed by the rhyme, e.g.: الظنونا /az-zunūnā/ 'the assumptions' (Q33:10), الرسولا /ar-rasūlā/ 'the messenger' (Q33:66) and السبيلان /as-sabīlā/ 'the 
way' (Q33:67). To this we may add as well the diptotic plural with an apparent diptotic accusative ending: قو اريرا /qawārīrā/ 'crystal clear' (Q76:15, 16) سلسلا /salāsilā/ 'chains' (Q76:4).

In other cases, the spelling is not changed, but the rhyme that such words appear in make it clear that they are to be read with final $/-\bar{a} /$, thus every other case of the accusative of as-sabül in rhyme is spelled السبيل but certainly rhymed /as-sabīlā/ (Q4:44, Q25:17, Q33:4). Likewise, two subjunctives seem to rhyme

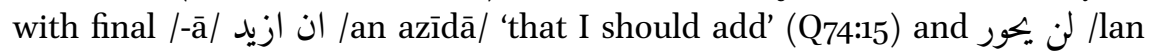
yahūrā/ 'he will not return' (Q84:14). Note that these are isolated exceptions, and both the definite accusative and the subjunctive occurs hundreds of times in rhyme where they are not pronounced as /-âa/. How to understand the exceptional status of these rhymes (which mostly concentrate and Q33 and Q76) requires further research. ${ }^{57}$

\section{A.3.5 Assimilation Across Vowels}

A major feature of Quranic Arabic that distinguishes it quite clearly from later Classical norms is its assimilation of identical and coronal consonants across vowels, while some of these ambiguous cases lead to disagreement between the Quranic readers, there is not a single reading that shows no signs of this assimilation at all.

For assimilation across vowels where the consonants are identical, it mostly concers with the first-person clitics - $n \bar{\imath}$ and $-n \bar{a}$. The table below illustrates the examples. In some of these cases there is a disagreement between the regional codices, where one of the codices has an unassimilated form where the other does, in such cases $\mathrm{I}$ have given the abbreviated code $(\mathrm{S}=\mathrm{Syria}, \mathrm{M}=$ Medina, $\mathrm{B}=$ Basra, $\mathrm{K}=\mathrm{Kufa}, \mathrm{C}=\mathrm{Mecca}$ ) of the regional codex that has the minority variant. The unmarked version is then the variant that occurs in all other codices (see Sidky 2021; Cook 2004).

56 The form in Q76:16 does not occur in rhyme, but is the first word of the verse, directly following the previous word spelled like this. This being said, the later Basran codices seem to change this spelling to the expected قوارير. For a discussion on the reports on this spelling and its attestations in early manuscripts see Sidky (2021).

For a further discussion on these rhymes see also Van Putten \& Stokes (2018, 161-163). 


\begin{tabular}{|c|c|c|}
\hline QCT & Pronunciation & Quranic recitation \\
\hline (Q6:80) اتحجونى (Q) & /Ra-tuhāāğğūn-nī/ & 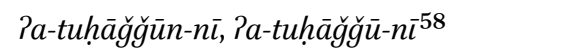 \\
\hline 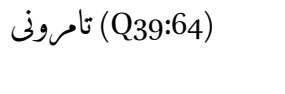 & /tāmurūn-nī/ & $\begin{array}{l}\text { tåmurūn-nī/-niya, tāmurūn-nī, tåmurū- } \\
\text { niya, tāmurū-niya } 59\end{array}$ \\
\hline تامرونتى (Q39:64, S) & /tāmurūna-nī/ & ta?murūna-nī \\
\hline تامنا (Q12:11) & /tāman-nā/ & 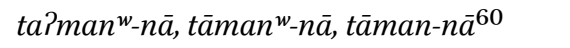 \\
\hline ) مكنى (Q18:95) & /makkan-nī/ & makkan-n $\bar{\imath}^{61}$ \\
\hline (Q18:95, C) & /makkana-nī/ & makkana-n̄̄ \\
\hline فنعما (Q2:271) & /fa-naYim-mā/ & 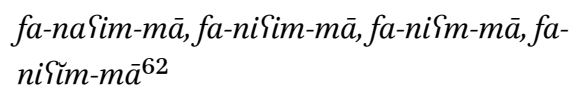 \\
\hline 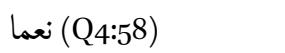 & /naSim-mā/ & 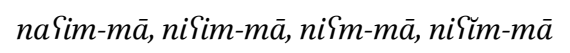 \\
\hline انى (Q2:30 \& passim) & /Pin-nī/ & Pin-ni \\
\hline انى (Q2:47 \& passim) & /Ran-nī/ & Pan-nī \\
\hline انا (Q2:14 \& passim) & /?in-nā/ & Pin-nā \\
\hline انا (Q4:66 \& passim) & /Ran-nā/ & Pan-nā \\
\hline لياتينى (Q27:21) & /la-yātiyan-nī/ & la-yaPtiyan-nī, la-yātiyan-n $\bar{\iota}^{63}$ \\
\hline لياتيننى (Q27:21, C) & /la-yātiyanna-n̄̄/ & la-yaPtiyanna-ni \\
\hline تزينى (Q23:93) & & turiyan-n̄̄ \\
\hline
\end{tabular}

One might be tempted to understand such assimilation taking place as evidence that in Quranic Arabic the intervening short vowels of these stems had been lost, even before clitics. Interpreted in this way, these would not be examples of assimilation across short vowels. For early Christian Arabic, which shows similar cases, e.g. اخخنى/Raxzan-nī/ 'he grieved me', امكنى /Ramkan-nī/ 'it was possible for me', يدينى /yadīn-nī/ 'you judge me'. Blau (1967, §35.4; § 41.4) indeed interprets these as evidence for that.

It is worth making several more observations here however: even when the previous consonant is completely unvocalized in the reading traditions, identical consonants following each other may be written twice, thus the jussive (Q4:78) recited as yudrik-kum '(death) will overtake you' is written with

\footnotetext{
58 Ibn al-Ğazarī (§ 3037$)$.

59 Ibn al-Ğazarī (§ 4091).

6o Ibn al-Ğazarī (§1209).

61 Ibn al-Ğazarī ( $(1208)$.

62 Ibn al-Ğazarī ( $(2806)$.

63 Ibn al-Ǧazarī ( $\$ 3801)$.
} 
two kāfs, يوجها (Q16:76) recited as yuwağğih-hu and يكرهن (Q24:33) recited as yukrih-hunna are written with two hā?s. But assimilation written out may also happen as found in the jussive تفتنى (Q9:49) recited as taftin-nì. As such, the fact that e.g. يدعونى (Q12:33) 'they call me' is written with two nüns does not necessarily prove the pronunciation /yad@ūna-nī/, it could just as well stand for /yadiūn-nī/ with morphophonological spelling. However, in light of the fact that nouns followed by pronominal clitics appear to have kept their final short vowels (A.3.4), it seems reasonable to assume that this is the case for verbs too. The examples given above are therefore not evidence for the lack of final short vowels, but rather examples of assimilation across vowels, a phenomenon of which there are many more examples in Quranic Arabic where we cannot propose the absence of an intervening vowel as we will see below.

Assimilation of identical consonants across a vowel also rarely occurs in the jussives of geminated verbs like yamdud. These forms are far outnumbered by cases where the metathesis did not take place, but it is worth mentioning all the cases here. If the same word also occurs elsewhere unassimilated, I have included them in this table as well. When regional variants play a role letter codes are given once again.

\begin{tabular}{|c|c|c|}
\hline QCT & Pronunciation & Quranic recitation \\
\hline ） يرتدد (Q2:217) & /yartadid/ & yartadid \\
\hline يرتدد (Q5:54, SM) & /yartadid/ & yartadid $^{64}$ \\
\hline ) & /yartadd/ & yartadda \\
\hline (Q27:40) يرتد & /yartadd/ & yartadda \\
\hline لشاقق (Q4:115) & /yušāqiq/ & yušāqiq $(i)$ \\
\hline ) يشاق & /yušāqq/ & $y u s ̌ \bar{a} q q(i)$ \\
\hline يضار (Q2:282) & /yuḍārr/ & yuḍārra, yuḍāar 65 \\
\hline تضار (Q2:233) & /tuḍārrr/ & tuḍārra, tuḍārru, tuḍār66 \\
\hline
\end{tabular}

Another place where the QCT irregularly has assimilation across short vowels is in the tD- and tL-stems, where the $t a$ - prefix may be optionally assimilated to the following coronal consonant. This may happen both in the suffix con-

$\begin{array}{ll}64 & \text { Ibn al-Ǧazarī (§ 2989). } \\ 65 & \text { Ibn al-Ğazarī (\$ 2774). } \\ 66 & \text { Ibn al-Ğazarī (\$ 2774). }\end{array}$ 
jugation and in the prefix conjugation, although in the latter it is much more common. The seven cases of this assimilation in the prefix conjugation are the following.

\begin{tabular}{|c|c|c|}
\hline QCT & Pronunciation & Reading Traditions \\
\hline فادرتح (Q2:72) & /fa-ddārātum/ & fa-ddāraitum $(\bar{u})$, fa-ddārātum $(\bar{u})$ \\
\hline (Q5:6) فاطهرو (Q) & /fa-țtahharū/ & fa-țtahharū \\
\hline (Q7:38) اداركوا & /iddārakū/ & iddāa $r a k \bar{u}$ \\
\hline اثاقلتم (Q9:38) & /ițtāqaltum/ & ittāāqaltum $(\bar{u})$ \\
\hline ) (Q10:24) وازينت & /wa-zzayyanat/ & wa-zzayyanat \\
\hline (Q27:47) اطيرنا & /iț̣ayyarnā/ & itțayyarnā \\
\hline (Q27:66) & /iddārak/ & iddāraka \\
\hline
\end{tabular}

For the prefix conjugation there are many more examples, but are cause for some disagreement between the readers. When a ya- prefix precedes an assimilated $\mathrm{tD} / \mathrm{tL}$-stem, all readers are in agreement that the prefix assimilates, but when it stands before a $t a$ - prefix, some rather see it as the haplological avoidance of the sequence $t a-t a->t a$-, similar to ولا تفرقو /wa-lā tafarraqū/ 'do not become disunited' (Q3:103) but ولا تتفرقو /wa-lā tatafarraqū/ 'id.' (Q42:13). As both haplology avoidance and assimilation occur in the QCT, it is not possible to be certain in those cases whether we are dealing with assimilation or haplology. The table below gives several illustrative examples of the problem using the common verb tadakkara as the basis for examples.

\begin{tabular}{|c|c|c|}
\hline QCT & Pronunciation & Reading Traditions \\
\hline يذكر (Q2:269) & /yaddakakar/ & yaddakkaru \\
\hline يتذكر (Q13:19) & /yatadakkar/ & yatadakkaru \\
\hline تتذكترون (Q6:80) & /tatadakkarūn/ & tatadakkarūna \\
\hline تذكرون (Q6:152) & /tadַdakkarūna/, /tad̄akkarūna/ & tadakkarūna, taddakkarūna \\
\hline
\end{tabular}

There is no way to decide what the intended pronunciation was of a second person, or third person feminine prefix conjugation verb when the next consonant can be assimilated, and the Quranic readings do not seem to retain a historical memory of it, and rather have complex generalized rules. For example, 
the Kufans always read $t a$ - followed by an assimilatable consonant assuming haplology (thus tadakkarūna), whereas the other readers always assume assimilation (thus tadِ dakkarūna) (Ibn al-Ğazarī § 3084).

Other coronal consonants may occur assimilated as well, are unattested in the prefix conjugation:

\begin{tabular}{|c|c|c|}
\hline QCT & Pronunciation & Reading Traditions \\
\hline (Q2:74) يشقق (Q) & /yaššaqqaq/ & yaššaqqaqu \\
\hline (Q2:158) & /yatțawwaf/ & yattawwafa \\
\hline يصدقوا (Q4:92) & /yașșaddaqū/ & yașșaddaqū \\
\hline (Q7:94) يضرعون (Q) & /yaḍḍarraYūn/ & yaḍ̣arraSūna \\
\hline 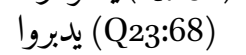 & /yaddabbarū/ & yaddabbarū \\
\hline (Q37:8) & /yassammaYūn/ & yassammaৎ̄una \\
\hline يزكى(Q80:3) & /yazzakkē/ & yazzakkā, yazzakkēe, yazzakkä̈ \\
\hline
\end{tabular}

As was the case with the assimilation of identical consonants across vowels, this type of assimilation is also cause for some disagreement between the regional codices, for Q7:3 the Syrian codex has تخذكرون recited by Ibn Yāmir as yatadakkarūna whereas the non-Syrian codices have تذكون variously recited as tadakkarūna or tadd dakkarūna. In light of the non-Syrian reading, the more natural reading of Q7:3 in the Syrian codex is probably tatadakkarūna, a reading that is indeed reported for Ibn Yāmir (as a non-canonical transmission) and for Pabū al-Dardā? (Ibn Xālawayh muxtașar, 42; Ibn Muǧāhid, 278). Pabū al-Dardā? was one of the companions of the prophet who indeed died in Damascus, and was one of Ibn Yāmir's teachers (Ibn al-Ǧazarī, § 627), it is therefore no surprise that he would have the expected Syrian variant.

The assimilation across vowels of $t a$ - to a following coronal may even happen if the $t a$ - is preceded by a consonant. This seems to occur in the Ct-stem istațā $\hat{\text { a }}$ 'to be able', but may, depending on the interpretation, also occur with the Gt-stems ihtada and ixtașama, for a discussion on the interpretation of the Gt cases see $\S 5.10$. The table below illustrates some examples. 


\begin{tabular}{|c|c|c|}
\hline QCT & Pronunciation & Reading Traditions \\
\hline استطاعوا (Q18:97) & /istațāYū/ & istațā $\subseteq \bar{u}$ \\
\hline اسطاعوا (Q18:97) & /isțțāYū/ & $i s t ̦ \bar{a} \subseteq \bar{u}$, istțāa $\bar{u}^{67}$ \\
\hline (Q18:78) & /lam tastațî/ & lam tastațiৎ \\
\hline (Q18:82) لم تسطع & /lam tasțți / & lam tasțiৎ \\
\hline (Qهتدى (Q10:108) & /yahtadī/ & yahtadī \\
\hline (Q10:35) & /yahddīi / (or /yahdī/?) & $\begin{array}{l}\text { yahiddī, yahaddī, yahădd } \bar{\imath}, \text { yahddī, } \\
\text { yahd } \bar{\iota}^{69}\end{array}$ \\
\hline تعتدوا (Q2:19o) & /ta9tadū/ & taStadū \\
\hline تعدوا (Q4:154) & /taYddū / (or / taYdū/?) & 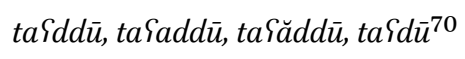 \\
\hline (Q26:96) & /yaxtașimūn/ & yaxtașimūna \\
\hline (Q36:49) & /yaxșșimūn/ or /yaxșimūn/ & $\begin{array}{l}\text { yaxișsimūna, yaxașșimūna, yax- } \\
\text { ășsimūna, yaxșșimūna, yaxșim- } \\
\text { ūna }{ }^{71}\end{array}$ \\
\hline
\end{tabular}

These examples should make it clear that syncope of short vowels between two identical consonants, and assimilation of $t$ to coronals across a vowel happens quite frequently all throughout the QCT. It seems to have always been optional, and for almost every single example of such a phenomenon there are examples where the assimilation did not take place as well. Its distribution does not present an obvious explanation for this variation. The fact that

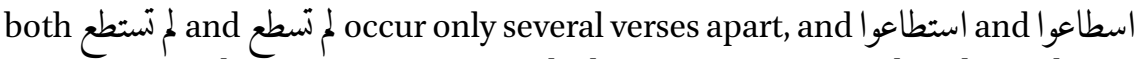
even occur in the same verse, give us little reason to suggest that this is due to multiple authors or scribes for different parts of the Quran. It seems that we must conclude that such assimilations across vowels were a free variant option in the language of the Quran, which infrequently occurred regardless of environment.

The freedom between different assimilated and unassimilated forms is in fact so close, that almost perfectly parallel verses may occur both with assimilated and unassimilated forms, for example:

67 Ibn al-Ǧazarī (\$ 3540$)$.

68 The Manuscript Ma VI 165 has تستطع for both Q18:78 and Q18:82.

69 Ibn al-Ğazarī $\left(\$ 3^{256}\right)$.

70 Ibn al-Ğazarī (\$ 2969).

71 Ibn al-Ğazarī (\$ 4010). 
Q6:42 wa-laqad Parsalnā Pilā ?umamin min qabli-ka fa-Paxadnāa-hum bil-baPsāPi wa-ḍ-ḍarrāî laSallahum yataḍarrạūna

We have sent already unto peoples that were before thee, and we visited them with tribulation and adversity, so that perhaps they might grow humble.

\section{Q7:94 wa-mā Parsalnā fi qaryatin min nabiyyin Pillā Paxadnā Pahla-hā bi- l-baPsāî wa-ḍ-ḍarrāî laSallahum yaḍ̣arraYūna}

And we sent no prophet unto any town except to visit its people with tribulation and adversity, so that perhaps they might grow humble.

Another case of this process is attested in the non-canonical readings, and is well-attested in vocalized Quranic manuscripts for the verb يخصفان (Q7:22; Q20:121) 'they covered (themselves)', which is read by the canonical readers as yaxșifāni but is attested vocalized as yaxașșifāni, yaxișsifāni in kufic manuscripts (e.g. Q7:22 in Arabe 334j; Q20:121 in Arab 325j, 347a), which is clearly an assimilated form of the Gt-stem yaxtasifanit. These forms are attested in the Šāḍd literature too, e.g. Ibn Xālawayh (muxtaṣar, 42, 90).

\section{A.3.6 Pausal Shortening of $-\overline{1}$}

Quranic Arabic has two realizations of word-final - $\bar{\iota}$, it can either be written with a $ى$ or with no mater at all. This concerns any type of word-final $y \bar{a}$ ?: (1) Final $-\bar{\imath}$ of definite III- $y$ nouns, e.g. الواد 'the valley' (Q89:9); (2) 1sg. Object pronoun -nī, e.g. فاتقون 'fear me' (Q2:41); (3) 1sg. possessive pronoun -ī, e.g. دين 'my religion' (Q109:6); (4) The -i of imperfect verbs (only once): يسر 'it passes' (Q89:4).

Van Putten \& Stokes $\left(2018,15^{6-158)}\right.$ showed that these shortened forms are overwhelmingly favoured in pausal positions. While long forms rarely occur in pause, and shortened forms only occasionally occur outside of pause. Thus, pause seems to be quite clearly the origin for the shortening. The fact that these forms stand in rhyme where the vowel is entirely unpronounced, suggests that the $-\bar{\imath}$ was not shortened, but dropped altogether, which would mean the pausal form of the isg. possessive marker was zero-marked.

\section{A.3.7 سيات Reflecting /sayyāt/}

Original *sayyirāt- 'evil deeds' in the CE is regularly spelled as السيات ,سيات seemingly with an ?alif in the position of the * $7 .{ }^{72}$ In early manuscripts this

72 This spelling also appears to be common in early Christian Arabic (Blau 1967, § 11.4.1.2B). 
spelling is not always regular. It is outside the scope of the current work to examine this spelling in every single manuscript. Instead, below I have listed the spellings for every single occurrence of the word in the CPP. It becomes clear that the spelling سييت, more in line with the normal orthographic practices of the QCT, occurs besides سيات.

$$
\begin{aligned}
& \text { سياتنا (Q3:193), سيته (Q3:195; Q25:70), سييتكم (Q10:27) سييتم (Q4:31; Q5:12; Q8:29), سييته (Q65:5) }
\end{aligned}
$$

As with most other CayyiC adjectives, sayyi? has a contracted by-form say? in Classical Arabic (Lane, 1491a, see also al-Farrā? Luġāt, 30), cf. dayyiq-, dayq- 'narrow' (Lane, 1868b), mayyit-, mayt- 'dead' (Lane, 28oob) and layyin-, layn- 'soft' (Lisān, 4117b). It seems then that the spelling سيات should be considered the outcome of this contracted form, i.e. /sayyāt/ or /sayāt/, whereas the spelling represents the uncontracted form /sayyiyāt/. The ?alif then is not a sign for the hamzah, but rather the result of the regular rule for the plene spelling of the plural feminine ending which occurs if the word would otherwise consist of only three letters (see Appendix A.2.1).

Whether the QCT indeed originally showed free variation between the contracted or uncontracted form, or whether the $\mathrm{CE}$ is correct in only showing the contracted form is a question that cannot be addressed in the current work.

\section{A.3.8 A Case of $\mathrm{N}$-Assimilation?}

While by no means regular, there are two examples in the QCT where the sequence of two nūns is simplified to just a single nūn, namely: Q21:88 نجى 'we save', Q12:110 فنجى 'so we save' (cf. Q10:103 نجى 'we save') which are read as nuğğ ing error that has been propagated from the archetype, this should probably be understood as an isolated case of an assimilated $n$ to the following $\check{g}$.

\section{A.3.9 The Genitilic Adjective Ending}

In most modern dialects, the gentilic adjective ending (Nisbah) is $-\bar{\imath}$ for the masculine and -iyya $(h)$ for the feminine. While the masculine form has become a fairly common place transcription of the Classical Arabic gentilic adjec-

73 Ibn al-Ğazarī ( $\$ 3354 ; \S 3633)$, who considered Q21:88 a hapological reduction of nunağğ Ibn Muğāhid (430), surprisingly considers it to be the passive perfect nuğğgiya with dropped final $-a$. This is grammatically quite problematic considering the following noun al-mu?minina is in the accusative. 
tive, normatively it is to be pronounced as -iyy even in pausal pronunciation. The Quranic rhyme suggests that the simplification of -iyy to $-\bar{\imath}$ took place in Quranic Arabic as well, whereas the indefinite accusative remained -iyya $\overline{\text {. }}$

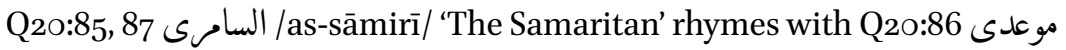
/mawSid-ī/ 'promise to me', Q20:88 فنسى /fa-nasī/ 'so he has forgotten' and Q20:95 يسمرى/yā-sāmirī/ 'O Samaritan!' rhymes with Q20:94 فولى /qawl-ī/ 'my word' and Q20:95 نفسى /nafs-ī/ 'my soul'.

Q19:16 مكانا شرقيا /makānā šarqiyyā/ 'an eastern location' rhymes with

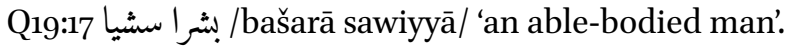

The feminine gentilic adjective ending would presumably have been /-iyyah/, but it is unattested in rhyme position.

\section{A.3.10 Palifal-wașl}

In Classical Arabic, there is a significant group of words that start with an initial vowel, which is elided when another vowel precedes it. ${ }^{74}$ These can be found in five main environments.

1. The definite article: (a)l-bašar

2. A small group of nouns such as (i)sm 'name', (i)bn 'son', (i)mru? 'man', (i)mraiah 'woman'.

3. Imperative verbs, $(i) f \uparrow a l,(u) k t u b$

4. Gt-, N- and Ct-stem verbs: (i)fta Sala, (i)nfaSala, (i)stafiala

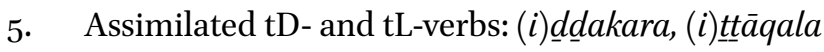

From the QCT, it is not at all clear that such an elision takes place in Quranic Arabic, as the prothetic vowel is spelled morphophonologically, so even when a particle precedes that would cause the ?alifal-wașl to be elided, is still written. From the orthography it is therefore equally possible that the ?alif was actually pronounced in such cases.

From the Damascus Psalm fragment, we learn that it need not be the case that all contexts of the Palif al-wașl are equal in this regard. There the ?alif alwașl of the definite article is elided in much the same way as in Classical Arabic

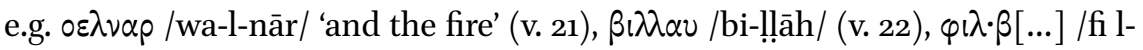
$\mathrm{b}$ [ariyyah]/ 'in the wilderness' (v. 52), $\varphi$ l $\lambda \cdot \beta \alpha \chi \varepsilon p$ /fi l-bašar/ 'among men' (v. 6o), $\lambda(\lambda \cdot \sigma \varepsilon \beta \cdot / \mathrm{li}-\mathrm{l}-\mathrm{sab}(\mathrm{y}) /$ 'into captivity'. However, the Gt- and N-stems seem to have a true hamzat al-qaț , e.g. $\propto \alpha \cdot \alpha \beta \cdot \tau \varepsilon \cdot \lambda \varepsilon \hat{v} /$ wa-Pabtalaw/ 'they tempted' (v. $\left.5^{6}\right)$ and $\varphi \alpha \cdot \alpha \nu \varkappa \alpha \cdot \lambda \varepsilon \cdot \beta(0) v \cdot /$ fa-Panqalabu / 'and they turned their backs' (v. 57) (for the analysis of the Damascus Psalm Fragment see Al-Jallad 2O2Ob, 79 ff.). As already

74 In poetry, the ?alif al-wașl may sometimes be treated as a true hamzah (Nöldeke 1896, 7). 
pointed out by Al-Jallad (2O2Ob, 51, 6o), it is therefore not a given that the QCT orthography represented a linguistic situation identical to Classical Arabic rather than the situation identical to that of the Damascus Psalm Fragment. In this section we will examine each of the five environments, and considered the evidence for the elision of the ?alif al-wașl in each of them.

In the QCT, it is regular to drop the Palif al-wașl of the definite article when

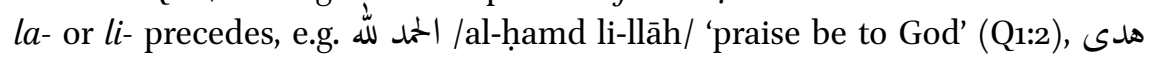

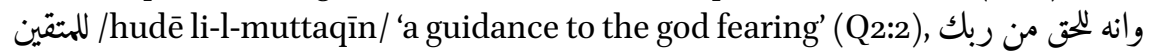
/wa-inna-h la-l-haqq min rabbi-k/ 'for this is indeed the truth from your lord' (Q2:149). In early manuscripts this behaviour is quite frequent, although never regular, when $b i$ - precedes the definite article. This is especially common in the phrase بالحق /bi-l-haqq/ 'with the truth' (Cellard 2018, 8), although not exclu-

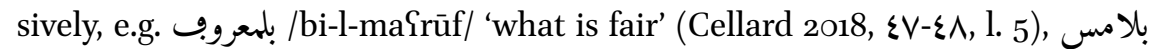

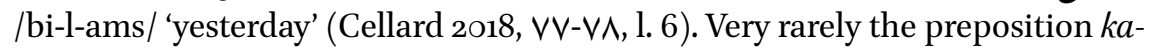
has the same effect, e.g. كلمهل /ka-l-muhl/ 'like molten brass' (Cellard 2018, 199r... l. 10). If $w a$ - or $f a$ - or $f \iota$ precede, the ?alif al-was $l$ is always written.

The only possible example that may be cited of an example where the ?alif al-wașl of the definite article is perhaps left unwritten is the phrase ولدار الاخره (Q12:109; Q16:30). This is recited as a construct phrase as wa-la-dāru l-(P)āxirati, however وللدار الاخره (Q6:32), recited as wa-la-d-dāru l-(?)āxiratu, ${ }^{75}$ suggests that this might not be a construct phrase with the asseverative particle $l a$ - in front of it, but rather the single lām represents the definite article, i.e. /wa-d-dār al-āxirah/ (Nöldeke et al. 2013, 397, fn. 56).

Despite the frequent morphophonological spelling then, it seems clear that indeed the vowel of the definite article was elided if a particle preceded. This is further confirmed by the fact that, occasionally, word-final long vowels are spelled defectively when they immediately precede a definite article, e.g. سوف sawf yūti (> yūtī) llāh al-mūminīn ağrā Yazīmā/ 'Allah

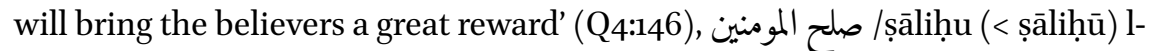

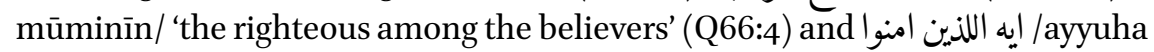
(< ayyuhā) l-mūminūn/ 'O believers!' (Q24:31) (see A.2.10).

There is very little direct evidence that the ?alif al-wașl on words such as imra?ah and imru? was elided. However, the basmalah formula is written بس. باسم الله This is a strong indication of the elision of this ?alif al-wașl. Outside of the basmalah, bi-smi occurs occasionally with the morphophonological spelling as well, though this is cause for some disagree-

75 Except by the Syrian canonical reader Ibn Yāmir who reads it wa-la-dārul-Pāxirati, because the Syrian Muṣhaf spells this ولمار الاخره rather than وللدار الاخره (Ibn al-Ǧazarī § 3017; Cook 2004, 92, (S4)). 
ment among early Quranic manuscripts, e.g. باسم ربك /bi-smi rabbi-ka/ (Q56:74) (see B.19). The CE attests يبنوم /ya-bna-wumm/ (Q20:94) 'O son of my mother!', which would be a good example of the elided Palif al-wașl before this word is consistently spelled يابنوم in early Quranic manuscripts (see B.20).

While several I-? verbs have irregular biradical imperatives such as kul 'eat!' and $x u \underline{d}$ 'take!', most verbs are treated as regular triradical verbs, with the loss of the hamzah in Quranic Arabic, however, these develop a special allomorphy, where the unprefixed imperative have an initial long vowel $/ \overline{\mathbf{l}} /$ whereas when they are prefixed by $w a$ - or $f a$ - these merged into /wā-/ and / fā-/.This behaviour can only be understood if we assume that such imperatives in an early stage of the language indeed had a non-phonemic initial $i$-in absolute initial position, *(i)?ti >/īt/ but *fa-?ti > /fāt/.

\begin{tabular}{|c|c|c|c|}
\hline & wa- & fa- & \\
\hline ايت /ît/ (Q10:15) & & فات /fāt/ (Q2:258) & 'come/bring!' \\
\hline \multirow{2}{*}{ ايتوا /ìtū/ (Q2O:64) } & واتوا /wātū/ (Q2:189) & فاتوا /fātū/ (Q2:23) & 'come (pl.)!' \\
\hline & & فاتيا /fātiyā/ (Q26:16) & 'come (du.)!' \\
\hline \multirow[t]{4}{*}{ } & & & 'permit!' \\
\hline & & فاذنوا /fādanū/ (Q2:279) & 'be informed (pl.)!' \\
\hline & وام/wāmur/ (Q7:145) & & ‘order!' \\
\hline & & فاوا /fāwū/ (Q18:16) & 'retreat (pl.)!' \\
\hline
\end{tabular}

While this behaviour clearly proves that such verbs had an Palif al-wașl historically, it is not entirely clear that this is the case synchronically. Verbs of this type do not have the same morphological behaviour as in Classical Arabic. For example: قل الذين لايرجون لقانا ايت بقران غير هذا او بدانله can really only be understood as / qāl allad̄inn lā yarğūn liqā?a-nā ît bi-qurān geayr hādā baddil-(u)h/ "Those who do not expect to meet us say: 'bring a recital other than this or change it'". Had the Classical pronunciation /liqā?a-na ?ti/ or with loss of hamzah /liqā?anāti/76 been intended, we would not expect ايت to have been spelled with the $y \bar{a}$ ?. This behaviour clearly cannot be attributed to pausal spelling, as had that been the case, we would expect the form with $w a$ - or $f a$-in front of it to also be written with the $y \bar{a}$ ?, i.e. ** فايت 'come/bring!.77

\footnotetext{
76 As is the recitation of Warš Yan Nāfiৎ, Pabū ĞaYfar and optionally for Pabū Yamr.

77 This is thus one of the many examples where the alleged "pausal spelling principle" is violated in Quranic orthography. See Van Putten \& Stokes $\left(2018,15^{2-158)}\right.$ for a more detailed discussion.
} 
Synchronically, it therefore seems that verbs of this type had a Palif al-qaț when there was not a direct proclitic in front of it. It seems possible that واغنفر 'and forgive!' (Q2:285), وانظ واعلي 'and see!' (Q2:259) 'and know!' (Q2:26) are read as /wa-g̈fir/, /wa-nzur/ and /wa-Ilam/ respectively, which would assume some amount of morphophonological spelling (something that is clear for the definite article as well) but alternatively /wa-ig̈fir/, /wa-unzur/ and /wa-âlam/ cannot be excluded. The fact that, unlike the definite article, we never find phonetic spellings without the prothetic ?alif may be interpreted as an indication that these indeed had ?alif al-qaț.

When $l i$ - and $l a$ - precede the definite article, they always trigger an elided spelling of the ?alif al-wașl. This is not the case when la-precedes the ?alif alwașl of derived verbs of the N-, Gt- or Ct-stem, which may suggest that, similar to the Damascus psalm fragment, these derived verbs indeed had a prefix ? $a$ rather than Palif al-waṣl, e.g. لاختلفت /la-Paxtalaftum/ 'you would have differed'

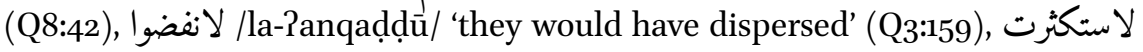
/la-Pastaktart/ 'I would have multiplied' (Q7:188).

There is one case against the presence of an Palif al-qaț in the Gt-stem. لتخذت 'you would have taken' (Q18:77) is recited as la-ttaxadtâ, la-ttaxatta by most readers, despite the absence of the ?alifal-wașl in the QCT. The reading of Ibn Kațīr, Pabū Yamr and YaYqūb is la-taxid̂ta, la-taxitta, which would not imply the elision of the ?alif al-wașl (Ibn al-Ǧazarī, §3525). However, it is quite clear that this is the inferior reading. Ittaxada is an irregular Gt-stem. Instead of the expected **i?taxada, Quranic Arabic treats it as a derivation of a I-w verb. The G-stem taxida is transparently an analogical backformation from ittaxada. As the G-stem of ittaxada is just the original Paxada everywhere else in the Quran, e.g. اخذتهم/Raxadtu-hum/ (Q22:44), it is difficult to accept the sudden use of taxida in this place only. Thus, the more natural reading of تلتخذ is indeed /la-ttaxadt/, which suggests that the ?alif al-wașl was unpronounced, in line with Classical Arabic, and different from the Arabic of the Damascus psalm fragment. There is however a question whether the spelling لتخذت is in fact archetypical to the UT. While a good number of manuscripts indeed exhibit this spelling, several quite ancient manuscripts point to the expected spelling لاتخذت such as Saray Medina 1a (corrected to لتخذت by a later hand) (see B.21). If the spelling with the elided ralif al-wașl is not original to the UT, then it once again becomes quite likely that the initial cluster was preceded by an ?alif alqaț instead.

Finally, the tD- and tL-stems as with the derive N-, Gt-and Ct-stems always write the Palif al-wașl with an Palif, regardless of whether it is preceded by a proclitic or not. However, the only proclitics that occur before it are wa/wa-(v)zzayyanat/ 'and is embellished', Q10:24) and fa- (فادرتم/fa-(v)ddārātum/ 
'so they disputed', Q2:72). These same proclitics also do not cause the elision of the ?alif al-wașl of the definite article in the orthography, which in proncuniation it was almost certainly unpronounced. As such, it is not readily possible to determine whether stems like these retained their epenthetic initial syllable if a clitic precedes.

\section{A.3.11 An Isolated Case of Word-Initial *wu > ?u}

The Arab grammarians record the possibility of shifting word-initial " $w u$ and * $w \bar{u}$ to $? u$ and $? \bar{u}$, e.g. wulida > $? u l i d a$, and in wuğ $\bar{u} h>? u g ̆ u ̄ h$ (Sỉbawayh IV, 331). This rule has made its way, not entirely regularly, into the textbook Classical Arabic as well (Fischer 2002, $\S 36 \mathrm{~b}$ ). While most of the time, this shift does not occur in the QCT, e.g. ولد (Q19:15) /wulid/ 'he was born' and (Q3:106) /wuğūh/ 'faces', there is a single occurrence of this development, namely, اقتT/Puqqitat/ 'the time has come' (Q77:11) root $\sqrt{\text { wqt t. }^{79}}$

\section{A.4 Morphology}

\section{A.4.1 Independent Pronouns}

Almost the complete paradigm of the independent pronouns is attested in the QCT, only the second person feminine plural is unattested.

\begin{tabular}{|c|c|c|c|c|c|c|}
\hline & & Singular & & Dual & & Plural \\
\hline $3 \mathrm{~m}$ & هو & /hū/, /huww/? & 100 & /humā/ & هم & /hum/ \\
\hline $3 \mathrm{f}$ & هي & /hì/, /hiyy/? & & & هن & /hunn/ \\
\hline $2 \mathrm{~m}$ & انت & /ant/ & انتما & /antumā/ & انتم & /antum/ \\
\hline${ }_{2} \mathrm{f}$ & انت & /ant/ & & & $r_{-}$ & \\
\hline 1 & انا & /anā/ & & & نخن & /naḥn/ \\
\hline
\end{tabular}

78 Pabū Samr reads wuqqitat and Pabū ĞaSfar reads this wuqitat, ignoring the dropping of the hamzah suggested by the rasm (Ibn al-Ğazarī § 4494).

79 This phenomenon is also aţtested occasionally in early Christian Arabic., Blau (1967, § 83)

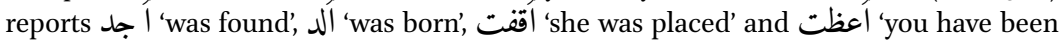
instructed'. 
From the fact that the masculine plurals are spelled $ه$ and rather than make it obvious that Quranic Arabic did not employ the long forms of the plural pronouns, unlike some of the Hijazi reading traditions ( $\$ 3.6 .5$ ).

The reconstruction of the phonetics of the third person singular pronouns requires some discussion. In the Sarabiyyah these pronouns are consistently huwa and hiya, unless they stand in an environment where they may syncopate to $w a-h w a$ and fa-hya (§2.2.4.3). From a Semitic perspective, the Sarabiyyah forms are surprising, the Hebrew forms $h \bar{u}$ הוא and a $h \bar{l}$ are best understood as reflexes of Proto-West-Semitic * $h \bar{u} ? a$ and ${ }^{*} h \vec{\imath} \vec{\imath} a$ (Suchard 2019, 211). Both the loss of length and the loss of the $*$ in the Sarabiyyah are irregular. Many modern dialects of Arabic have forms such as huwwa and huwwe (besides hiu, hī) (Fischer and Jastrow 1980, 80) which do not appear to be reflexes of *huwa and

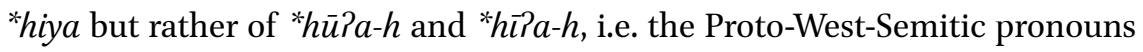
followed by the $-h$ pronominal extension also found in the Hebrew second person masculine pronoun Pattå < * Panta- $h$, and in the third person pronouns as well in the dead sea scrolls היאה ,הואה (Suchard 2019, 210). For a discussion on these stem extensions see Al-Jallad (2014b).

The expected reflex of Classical Arabic *huwa in Quranic Arabic, after the loss of final short vowels, would be **hu. As we saw in A.2.3, word-final $-\bar{u}$ is usually written with an Palif al-wiqāyah, and therefore the expected spelling of our hypothetical **hū would be هو. Instead, we regularly find هو, which would be the expected spelling for the reflex of *hū?a $>h u w w$. On this basis we might want to posit the third person pronouns as *hüpa $>/$ huww/ and *hiै?a $>$ /hiyy/ for Quranic Arabic. However, the fact that the pausal form (Q101:10) rhymes as /hiyah/, seems to suggest that Quranic Arabic indeed goes back to a form closer to the one we find in Classical Arabic instead, which would make a reading as $/ \mathrm{h} \overline{\mathrm{u}} /$ and $/ \mathrm{h} \overline{\mathrm{i}} /$ more attractive, in which case the spelling of irregular..$^{80}$

\section{A.4.2 Clitic Pronouns}

The pronominal system of the Quranic reading traditions shows a large amount of variation, most of which is not continued in Classical Arabic (van Putten and Sidky forthcoming). As final short vowels are lost in Quranic Arabic, some of this variation present in the reading tradition was presumably not expressed at all. It is unclear to what extent there was vowel harmony between the case vowel and the following pronominal suffix in the masculine plural clitics, but

8o Al-Farrā? (Luġāt, 29) reports that Banū Pasad uses hū and hī for huwa and hiya, and he cites poetry using the $h \bar{\imath}$ form. Such monosyllabic forms of the independent pronouns occur on occasion in poetry. 
reports of grammarians suggest that it was typical of the Hijaz to not have vowel harmony. This leads me to tentatively suggest that Quranic Arabic lacked vowel harmony as well, although there is no independent way to confirm this.

Lengthened forms of the singular pronouns $-h \bar{u}$ and $-h \bar{\imath}$ were certainly absent, as we would expect those to have been written as I and a The same is true for the lengthened pronominal forms -humū, -himi, himū and -kumū which would be expected to be written I كمو I. The long form of the second person plural pronoun only occurs four times before other clitic pronouns (Q8:44; Q11:28; Q15:22; Q47:37). The table below illustrates the probable reconstruction of the pronominal suffix paradigm.

\begin{tabular}{|c|c|c|c|}
\hline & Singular & Dual & Plural \\
\hline $3 \mathrm{~m}$ & a /-h/ & Lof /-humā/ & of /-hum/ \\
\hline $\begin{array}{l}3 \mathrm{f} \\
2 \mathrm{~m}\end{array}$ & \& /-hā/ & & $\begin{array}{l}\text { if /-hunn/ } \\
6 \text { \& } / \text {-kum/, }\end{array}$ \\
\hline $2 \mathrm{f}$ & ك |-k/ & K /-kumā/ & $\begin{array}{l}\text { /-kumū-/ (before pronouns) } \\
\text { كم /-kunn/ }\end{array}$ \\
\hline $1($ verbal $)$ & $\begin{aligned} 6 & \mid-n \overline{1} /, \\
ن & \mid-n / \\
ن & |-\overline{1} /, / \bar{v}-y /,| \bar{e} /, \\
\varnothing & -\varnothing\end{aligned}$ & & L /-nā/ \\
\hline
\end{tabular}

Special mention needs to be made of the 1sg. pronoun which has several different allomorphs. Due to pausal shortening of final ${ }^{*}-\grave{\imath}$ both the verbal $/-n \bar{i} /$ and nominal /-i/ also occur as /-n/ and /- $\varnothing /$ respectively (see A.3.6). After long vowels, the 1sg. nominal suffix is $/-y /$. Finally, there likely was a special vocative 1sg. marker that shows up in expressions of woe, e.g. ياسفى /yā-Pasaf-è/ 'O my sorrow!' (Q12:84), يحسرتى /yā-hasrat-ê/ 'O my regret!' (Q39:56), and يوليتي /yāwaylat-ē/ 'Woe is me!' (Q5:31; Q11:72; Q25:28). While technically the spelling with ${ }_{\varsigma}$ could be read as $-\bar{\imath}$ as well, ${ }^{81}$ the normal 1sg. ending, this is unlikely to be the intended reading here. Vocatives throughout the Quran consistently have the short pausal 1sg. ending, e.g. يقوم/yā-qawm- $\varnothing /$ 'O my people!', يابت /yā-abat-

81 Indeed, some non-canonical readers would read it as such, see Ibn Xālawayh (muxtașar, $32)$. 
$\varnothing /$ / 'O my father!', يرب/yā-rabb- $\varnothing$ / 'O my lord!! 82 Had the vocatives of woe had the normal 1sg. ending, we would have expected it to have been shortened as well. Moreover, in the canonical Quranic reading traditions this vocative 1sg. is indeed consistently read as $-\bar{e} /-\bar{a} /-\bar{a}$, as expected (Ibn al-Ğazarī, § 1973, § 20412042).

The first singular possessive clitic $-\bar{\imath}$ occurs a few times in pausal position (all in Q69) with a final $h$, clearly confirmed by the rhyme to represent a reading /-iyah/: كتبيه / حسابيه /hitāb-iyāāb-iyah/ 'my reckoning' (Q69:20; Q69:26); ماليه /māl-iyah/ 'my property' (Q69:28) سلطنيه /sulțāniyah/ 'my authority' (Q69:29). Elsewhere in the Quran the pausal 1sg. /- $\varnothing /$ is used in verse final position.

\section{A.4.3 Verbal Endings}

The suffix conjugation of the perfective verb appears to have been identical to the pausal pronunciations of Classical Arabic. The ip suffix /-nā/ is always spelled defectively in the QCT when it is followed by a pronominal clitic. This is presumably defective spelling, and does not indicate an actual shortening of the suffix to /-na/ in that context.

\begin{tabular}{|c|c|c|c|c|c|}
\hline & & Singular & & Dual & Plural \\
\hline $3 \mathrm{~m}$ & $\varnothing$ & $-\varnothing$ & & $\mid-\overline{\mathrm{a}} /$ & $\begin{array}{l}\text { I }|-\bar{u}| /|-\mathrm{aw}| \\
g|-\mathrm{w}|\end{array}$ \\
\hline $3^{f}$ & ت & -at/ & تـا & /-atā/ & ن |-n/ \\
\hline $2 \mathrm{~m}$ & ت & $|-\mathrm{t}|$ & تما & /tumā/ & $\begin{array}{ll}\text { |-tum/ } \\
\text { تمم } \text { /-tumū-/ (before clitic pronouns) }\end{array}$ \\
\hline $2 f$ & ت & $|-\mathrm{t}|$ & & & / / -tinn/ \\
\hline 1 & ت & $|-\mathrm{t}|$ & & & 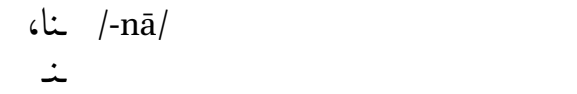 \\
\hline
\end{tabular}

The third person masculine plural ending $/$ /aw/ would be the form that occurs in verbs that end in ?alif maqșürah. This is indistinguishable from $/-\bar{u} /$ in the orthography of the QCT, but it seems reasonable to assume that Quranic

82 This, incidentally, seems to suggest that in the original prosody of Quranic recitation, such epenthetic vocatives had a minor pause following them, explaining the pausal form. 
Arabic retained this distinction. The third person masculine plural ending و و /$\mathrm{w} /$, never followed by an Palif al-wiqāyah occurs on hollow roots with hamzah as final root consonant such as جاو /ḡâw/ 'they came' (e.g. Q3:184) and also راو /rāw/'they saw' (e.g. Q7:149). ${ }^{83}$

The prefix conjugation has two different sets of ending, depending on whether it represent the imperfective, or the subjunctive/jussive. Invariably the imperfective form is longer, and those forms are given in between brackets when necessary. The vowel of the prefix appears to have occurred in two forms either with an $a$ (used for the G-, tD-, tL-, Gt-, N- and Ct-stems) and $u$ (used for the D-, L- and C-stems). In Quranic Arabic there was no alternation in the prefix vowel between $a$ and $i$ as reported for some eastern dialects (see $\S 4.7$ ).

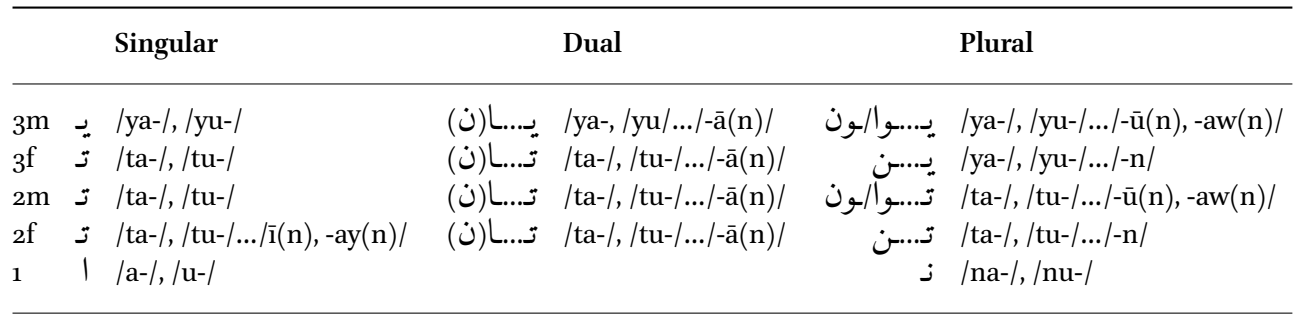

\section{A.4.4 Demonstrative Pronouns}

The near deixis demonstrative pronouns of Quranic Arabic have much less variation than is reported for Classical Arabic. It is seemingly a Hijazi innovation to always prefix the deictic pronouns with $h \bar{a}$ - (see $\S 4.5)$, save for certain specific archaic constructions, where traces of the ancient forms without $\underline{d} \bar{a}$ are retained (see below).

\begin{tabular}{|c|c|c|c|}
\hline Near deixis & Singular & Dual & Plural \\
\hline $\begin{array}{l}\text { masculine } \\
\text { feminine }\end{array}$ & $\begin{array}{l}\text { هذ/hādāā/ } \\
\text { هذهādih/ }\end{array}$ & 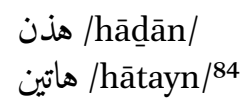 & هولا /hāwulā?/ or /hawlā?/ \\
\hline
\end{tabular}

83 See A.2.3 for the discussion of the use of the ?alif al-wiqayah and §5.11 on the Quranic Arabic use of /rāi/ and /nā?/ instead of Classical raīā and na?ā.

84 The plene spelling of this pronoun seems to be the common spelling in early Quranic manuscripts (see B.29). 
In Classical Arabic, the dual of the near deixis inflects for case, as a dual noun would, i.e. nom. hädāni gen./acc. hädayni. There is no evidence that this is the هذان خصمان / hādān xaṣmān/ 'these are two enemies', with nominative function, and the other is the famous verse Q20:63 ان هذن لاسيرن /in(n) hādāni la-sāhirān/ 'indeed, these are two magicians', where it functions as an accusative, where Classical Arabic would require hā $\underline{d} \bar{a} y n i$. However, as this is the only attestation of the near deixis dual pronoun in an accusative position, there is no reason to believe that this dual inflected for case.

The feminine dual is only attested in the gen./acc. and has the expected form هاتين. This could either mean that at an earlier stage of Quranic Arabic, it did inflect for case and the masculine and feminine generalized different case forms, or that Q20:63 really is an error.

The far deixis in Quranic Arabic is marked by the deictic pronominal base, followed by a typically Hijazi element $-l(i)$ - in the singular followed by the second person pronoun suffix, which can agree with the addressee.

\begin{tabular}{|c|c|c|c|}
\hline Far Deixis & Singular & Dual & Plural \\
\hline \multirow[t]{4}{*}{ masculine } & ذلك /dِāli-k/ (2sg.) & ذنك /dِāni-k/ (2sg) & اوليك /ulāyi-k/ (2sg.) \\
\hline & ذلكما /dāli-kumā/ (2du.) & - & - \\
\hline & ذلكم / ذفāli-kum/ (2pl.m.) & - & اوليكم /ulāyi-kum/ (2pl.m.) \\
\hline & ذلكن /dِāli-kunn/ (2pl.f.) & - & - \\
\hline \multirow[t]{4}{*}{ feminine } & تلك /til-k/ (2sg.) & - & \\
\hline & تلكم/til-kumā/ (2du.) & - & \\
\hline & تلك /til-kum/ (2pl.m.) & - & \\
\hline & - & - & \\
\hline
\end{tabular}

While تلك and can clearly be used in environments where the addressee is plural, the other forms seem to always be explicitly used in addressee agreement. Fischer $(2002, \S 275.2)$ suggests that the addressee agreement in preclassical Arabic no longer holds. This may be true for the poetry where these forms occur, but the system is evidently productive in the Quran. ${ }^{85}$

The locative deictics follow the same pattern as the pronominal deictics, where the near deixis always has the prefix $h \bar{a}$ - and the far deixis always

85 Al-Mubarrad (III, 275) discusses the full system of addressee agreement. 
has the -li- stem extension. There is no evidence for addressee agreement for the locative deictic.

\begin{tabular}{lll}
\hline & Near deixis & Far deixis \\
\hline Locative & هنالك/hāhunāanāi-k/
\end{tabular}

The Arab grammarians report forms of the short demonstrative without prefix $h \bar{a}$ - as a possible forms, this use of $\mathbf{~}$ / d $\mathbf{d} \bar{a} /$ has fallen out of use in Quranic Arabic. In the QCT it is only attested after the interrogatives من /man/ 'who' and ما /mā/ 'what'. The long interrogative /man dēā/ is only used in the cleft construction من ذا الذى /man dea alladīi/ 'who is it that ...?' (Q2:245, 255; Q3:16o; Q33:17;

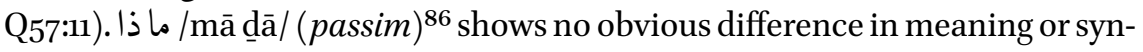

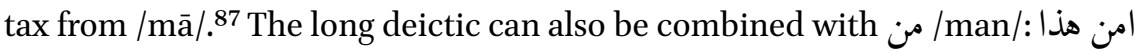
الذى /Pam-man hādā allad̄ī/ 'or who is it that ...?' (Q67:20, 21).

Classical Arabic has a construction of independent pronouns followed by the deictic elements with a presentative function. In such cases, the deictic lacks the $h \bar{a}$ - prefix but it may stand in front of the independent pronoun e.g. hā-Pana $\underline{d} \bar{a}$ 'here I am!', Panta $\underline{d} \bar{a}$ 'here you are', hä-nahnnu ?ulā?i 'here we are!' (Fischer 2002, § 279). Quranic Arabic attests this construction twice, both times with plural pronouns: هانت اولا تحبنهم/hā-antum ulā? tuhibbūna-hum/ 'Here you

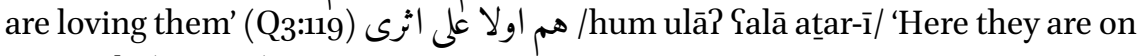
my track' (Q20:84).

Such constructions may also have the $h \bar{a}$ - prefix on the demonstrative after the pronoun, and the $h \bar{a}$ prefix may also occur on both: انتم هولا تقتلون انفسك /antum hāwulā? taqtulūn anfusa-kum/ 'Here you are killing one another'

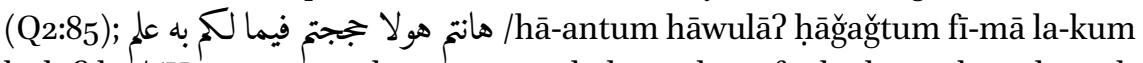
bi-h Silm/ 'Here you are, having argued about that of which you have knowledge' (Q3:66), see also $\mathrm{Q}_{4}: 109$ and $\mathrm{Q}_{47}: 38$.

86 This word is normally interpreted as a single word $m \bar{a} d \underline{a}$ and written as such in typewritten Arabic. There is no way to distinguish ما ذا ذاذا in handwritten Arabic, as a space between unconnected letters is of the same size in between words as within it. In light of من above, it seems best to interpret the form as /mā diā/ in Quranic Arabic. The ambiguity whether these phrases should be seen as one word or not seems to also underlie the reports that the Muṣhafs of Ibn Masfūd would write man $\underline{d} \bar{a}$ as a single word Farrā? Ma ānīi, III, 132).

87 Sỉbawayh (II, 416-419) specifically discusses constructions of this type. 


\section{A.4.5 Relative Pronouns}

The relative pronouns, unlike the Classical Arabic spelling, is spelled with a single lām in Quranic Arabic in all its forms. ${ }^{88}$

\begin{tabular}{|c|c|c|c|}
\hline & Singular & Dual & Plural \\
\hline masculine & الذى /alladīi/ & $\begin{array}{l}\text { nom. الذان /alladāan/ } \\
\text { obl. الذين /alladayn/ }\end{array}$ & | /alladīn/ \\
\hline feminine & /allatī/ التى / & - & 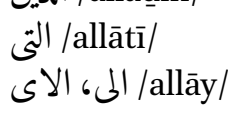 \\
\hline
\end{tabular}

While Classical Arabic allows for two forms of the feminine plural relative pronoun, the form besides allāt $\bar{i}$ is normally allawātì. Such a form does not occur in the Quran. Instead, a pronoun spelled variously in early manuscripts as الاى or الى presumably /allāy/, is used, with no discernable difference in function. ${ }^{89}$ Where the other pronominal forms are quite clearly the definite article $a l-+\mathrm{a}$ particle la followed by a demonstrative element, the origin of the /-āy/ of /allāy/ is not entirely clear.

\section{A.4.6 The Relative Possessive Demonstrative}

The relative possessive demonstrative which created constructions like "those of X" inflect for case and gender. For the plural two competing stems occur, the $/$ ulū $\overline{\mathbf{l}} /$ and / dawī/.

\begin{tabular}{|c|c|c|c|}
\hline & Singular & Dual & Plural \\
\hline masculine & 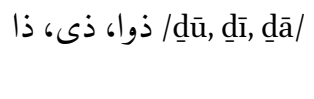 & / ذوا، ذوى / dawā, daway/ & 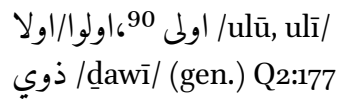 \\
\hline feminine & أذفāt/ ذات / & /dawātā, dַawātay/ ذواتا، ذواتى / & l اولت /ulāt/ اولت \\
\hline
\end{tabular}

88 This is a spelling practice it shares with early Christian Arabic (Blau 1967, § 26.3.2).

89 It is tempting to see in الى the ubiquitous relative pronouns illi of the modern dialects, but the spelling الاى seems to preclude such an interpretation. It is, moreover, unclear how a pronoun as rare as the feminine plural relative pronoun would be likely to spread to all positions and become the dominant relative pronoun.

When $u l \bar{u}$ stands before a CC cluster, early Quranic manuscripts frequently write the 


\section{A.4.7 Short Compound Interrogatives with $m \bar{a}$}

Prepositional compounds with $m \bar{a}$ occur several times in the Quran in short forms, where the interrogative is only written as a single mim. All of these occur besides the long form. Whether the lack of an Palif should be understood as them ending in a short $/ \mathrm{ma} /$, or ending in $/ \mathrm{m} /$ cannot be deduced from the QCT, and is dependent on the relative chronology of these shortened forms in Quranic Arabic. It is worth noting that these shortened forms predominantly occur when the combination of preposition $+m \bar{a}$ is interrogative in function, only Q86:5 appears to have a relative function with the short مم.

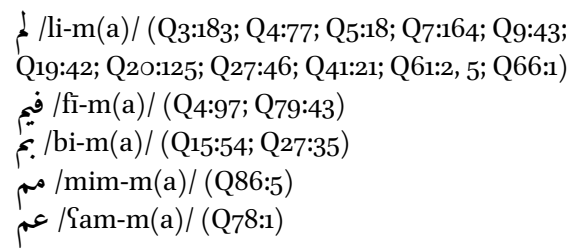
U /li-mā/ (e.g. Q2:41)
ما في /fĩ mā/ (e.g. Q2:240)

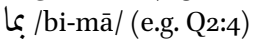

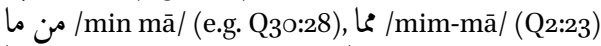

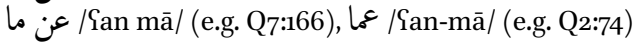

S 'how much?', which in Classical Arabic is invariably read as kam, may also be considered the result of this historical shortening of - $m \bar{a}$ in compound interrogatives, with lexical specialization. Historically, it seems to derive from *ka-mah literally 'like what?', as can be seen in Semitic comparanda such as Hebrew kammå 'how much?' (with irregular gemination also found in låmmå 'why?') and Aramaic kamā, kammā 'how much?' (Brockelmann 1908, 326). The fact that the form ends up as kam in the Classical language and not as kama might be an indication that the shortened pronoun was indeed pronounced $/-\mathrm{m} /$ in Quranic Arabic, rather than /-ma/.

The semantic development of $k a-m \bar{a}$ 'like what?' $\rightarrow k a-m a$ 'how much?' also finds a parallel in another interrogative with the same meaning, namely $\mathrm{ka}$ Payyin, likewise 'like' + 'what?', as attested in the Quran in the phrase كاين من 'how much of!' (Q3:146; Q12:105; Q22:45, 48; Q29:60; Q47:13; Q65:8), with fossilized nunation written out (see van Putten and Stokes 2018, 170). In Classical Arabic ka-Payyin can even have the interrogative function of kam 'how much?' (Lane, 134a) rather than only serving as an expression wonder.

demonstrative as اولا. The reasons for this are not entirely clear. For a rather speculative account on this phenomenon see Puin $(2011,154)$. See also Sidky $(2021)$ for a discussion of this phenomenon, but also lacking a solution. A dedicated study of this orthographic phenomenon is warranted. 


\section{A.4.8 Noun Inflection}

Van Putten \& Stokes (2018) have argued that Quranic Arabic had a reduced case system where only triptotic nouns distinguished the indefinite accusative with /-âa but otherwise lost inflect, except in construct. Case was retained in the Dual and Sound masculine plural. The paradigms of nouns can be reconstructed as follows:

\begin{tabular}{|c|c|c|}
\hline Indefinite & Definite & Construct \\
\hline nom. كتب /kitāb/ (Q2:89) & الكتب /al-kitāb/ (Q2:2) & كتب /kitābu/ (Q11:17) \\
\hline gen. كتب /kitāb/ (Q2O:52) & الكتب /al-kitāb/ (Q2:85) & كتب /kitābi/ (Q5:44) \\
\hline acc. كتبا /kitābā/ (Q3:145) & الكتب /al-kitāb/ (Q2:44) & كتب /kitāba/ (Q4:24) \\
\hline
\end{tabular}

Triptotes

Indefinite

Definite

Construct

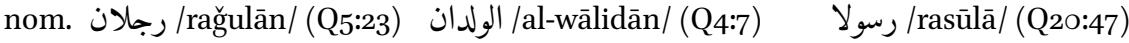

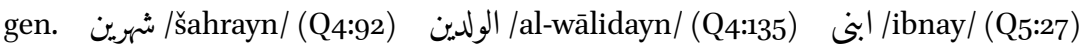

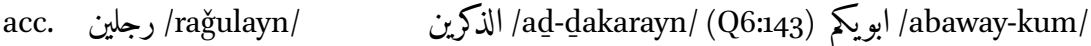
(Q16:76) (Q7:27)

Dual

\begin{tabular}{|c|c|c|c|}
\hline & Indefinite & Definite & Construct \\
\hline nom. & بنون /banūn/ (Q26:88) & البنون /al-banūn/ (Q18:46) & بنوا /banū/ (10:90) \\
\hline obl. & بنين /banīn/ (Q17:6) & البنين /al-banīn/ (Q37:153) & بني /banī/ (Q17:4) \\
\hline
\end{tabular}

Sound masculine plural 


\begin{tabular}{|c|c|c|c|}
\hline & Indefinite & Definite & Construct \\
\hline nom. & مغنم /mag̉ānim/ (Q4:94) & القوعد /al-qawāSid/ (Q24:60) & $\begin{array}{l}\text { ¿'متّ/mafātiḥu/ } \\
(\mathrm{Q} 6: 59)^{91}\end{array}$ \\
\hline gen. & مغنم /mag̉ānim/ (Q48:15) & القوّعد /al-qawāYid/ (Q2:127) & $\begin{array}{l}\text { (Q1, مسكن:45) } \\
\text { (Qmasākini/ }\end{array}$ \\
\hline acc. & مغنم /mag̉ānim/ (Q48:19) & القوّعد /al-qawāSid/ (Q16:26) & $\begin{array}{l}\text { (Q2:114) } \\
\text { (Qسجد /masāğida/ }\end{array}$ \\
\hline
\end{tabular}

Diptotes

\begin{tabular}{|c|c|c|c|}
\hline & Indefinite & Definite & Construct \\
\hline nom. & رحم/rahmah/ (Q2:157) & الرحمه /ar-rahmah/ (Q57:13) & رمت /rahmatu/ (Q11:73) \\
\hline gen. & رحم/raḥmah/ (Q2:159) & الرحمه /ar-rahmmah/ (Q17:24) & $\begin{array}{l}\text { رحم/raḥmati/ (Q15:56) } \\
\text { رحم/rahmati/ (Q19:2) }\end{array}$ \\
\hline acc. & رحم/rahmah/ (Q3:8) & /ar-rahmah/ (Q6:12) الرحمه / & $\begin{array}{l}\text { رحم/raḥmata/ (Q39:9) } \\
\text { رحمت/rahmata/ (Q2:218) }\end{array}$ \\
\hline
\end{tabular}

Feminine singular

Indefinite

Definite

Construct

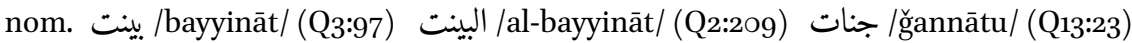

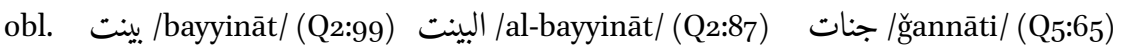

Sound Feminine plural

\section{A.4.9 III-w and III-y Nouns with Preceding a Vowel.}

Nouns that end in stem-final *-ay-and *-aw-, unlike Classical Arabic, appear to be distinct in Quranic Arabic, where the former collapsed to /e/e and the latter to $/ \bar{a} /(\S 5.8)$. The tables below give paradigm for both types of nouns.

91 The use of the plural pattern CaCāCiC for 'keys' is somewhat surprising. Strict Classical Arabic grammar would require the plural of miftāh to be mafātīh. The use of this pattern for stems with a long vowel in the last syllable seems to be more common in early Islamic Arabic papyri (Hopkins 1984, §87b). Generalization of $\mathrm{CaCāCiC}$ over CaCāCīC is also a 


\begin{tabular}{|c|c|c|c|}
\hline & Indefinite & Definite & Construct \\
\hline nom. & هدى /hudē/ (Q2:2) & الهدى /al-hudē/ (Q2:120) & هديهم / هudē-hum/ (Q2:272) \\
\hline gen. & هدى /hudē/ (Q2:5) & الهدى /al-hudē/ (Q17:94) & هديهي / /hudē-hum/ (Q16:37) \\
\hline acc. & (هد /hudē/ (Q17:2) & الهدى /al-hudē/ (Q2O:47) & هدى الله /hudē llāhi/ (Q6:71) هد الله \\
\hline
\end{tabular}

Words that end in $/ \bar{a} /$ are rarer, and thus a full paradigm cannot be recovered.

\begin{tabular}{|c|c|c|}
\hline Indefinite & Definite & Construct \\
\hline nom. & & عصاك / عașā-k/ (Q7:117) \\
\hline gen. & الصفا /aṣ-ṣafā/ (Q2:158) & بعصاك/bi-Sașā-k/ (Q26:63) بع/ك \\
\hline acc. & & عصاه / عașā-h/(Q7:107) \\
\hline
\end{tabular}

\section{A.4.10 III-w/y and III-P Nouns}

Final weak nouns whose stem ends in historical *-iy-such "wädiy- 'valley, river' have some amount of variation due to the appearance of shortened forms of the stem-final $-\bar{\imath}$. The defective spelling of the definite form is especially common in pause, and seems to be the result of a process of pausal shortening of final $\iota$ that we find throughout the Quran (see A.3.6). The short spellings in construct are presumably simply context spellings of the shortening of the long vowel before the CC cluster of the following definite article.

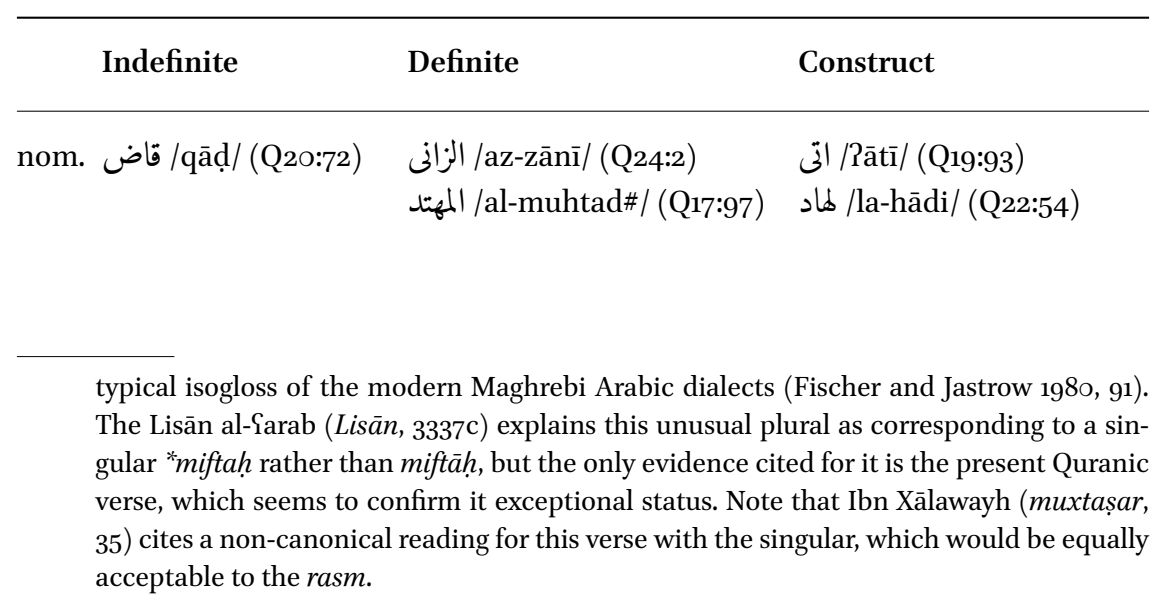


(cont.)

Indefinite Definite Construct

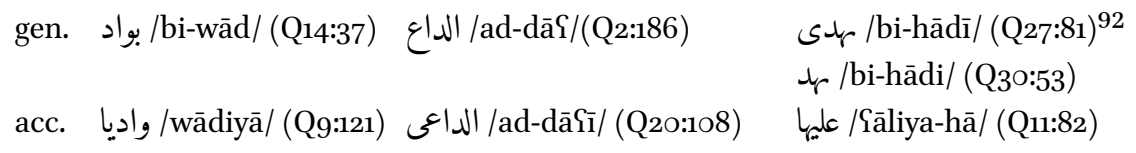

As in Classical Arabic, final weak plurals that are in origin diptotic have a slightly different form in the indefinite accusative form, lacking the final /-āa. Here again we find shortened forms in the definite forms (besides long forms) although they do not occur in obvious pausal positions.

\begin{tabular}{|c|c|c|c|}
\hline & Indefinite & Definite & Construct \\
\hline \multirow{2}{*}{$\begin{array}{l}\text { nom. } \\
\text { gen. }\end{array}$} & غواش /ġawāš/ (Q7:41) & الجوار /al-ğawār/ (Q55:24) & \\
\hline & ليال /layāl/ (Q69:7) & 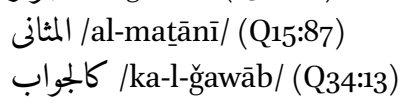 & $\begin{array}{l}\text { (Q33:5) موليكم /mawālī-kum/ } \\
\text { (Q) }\end{array}$ \\
\hline acc. & مولى /mawālī/ (Q4:33) & المولى /al-mawālī/ (Q19:5) & \\
\hline
\end{tabular}

Nouns which end in an original stem-final *-i?- are barely attested, but when they appear, they seem to behave identically to final weak nouns, although pausal forms with shortening are unattested.

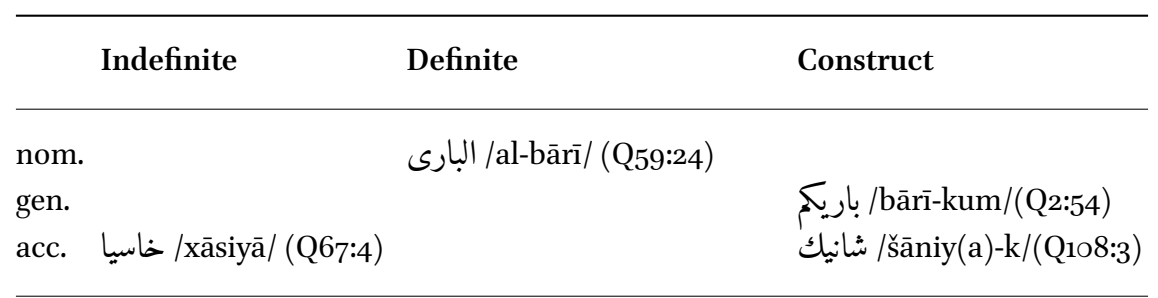

One other noun that has a hamzah-final stem is المنشيت (Q55:24). This word is spelled in the CE as المنشات, but this is clearly not original to the UT, as all

92 Q27:81 and Q30:53 are read by hamzah as tahdi l-umya (Ibn al-Ǧazarī: §3825). 
early manuscripts retain the spelling المنشيت (see B.22). This word is read by the majority of the readers as a passive participle of ?anša?a, i.e. munša?āt '(sails) raised', whereas Ḥamzah reads it as an active participle munši?āt 'raising (its sails)' (Ibn al-Ğazarī, §4316). The rasm is only consistent with Ḥamzah's reading, pointing to /munšiyāt/. If the majority reading is indeed intended, it means that the adjective munša? has merged completely with III- $y$ adjectives, and must be understood as coming from a paradigm m.sg. */munšē/ m.pl */munšawn/; f.sg. */munšēh/ f.pl. /munšayāt/.

The noun which in Classical Arabic would be sayyi? is consistently spelled in early Quranic manuscripts (van Putten 2018, 115). This is similar to verbs ending in the same sequence: هيا hayyi? (Q18:10) and yursyayyi? (Q18:16). The reasons for this are unknown. It is tempting to see this as a historical hamzah spelling.

\section{A.4.11 Nouns in *-ā? in Construct}

In the discussion of the ?alif al-wiqayah above, we already saw that nouns ending in $-\bar{a}$ ? in the construct nominative sometimes are spelled not with final $?$ alif, as is the normal spelling, but rather with ?alif+wāw (most notably with $\check{g} a z \bar{a} ?$ ?spelled as جزاو (بنوا ا (see B.11 and B.14). Also, the genitive is occasionally expressed with a glide $y \bar{a}$ ? in construct. This seems to be reconstructible for the following words in the UT: تلقى 'the accord of' (Q10:15), اناى 'the hours of' (Q20:130) and perhaps als 'ايتاى 'the giving of' (Q16:90) (see B.23).

When nouns of this type are followed by a pronominal clitic, they always reflect the case vowel with $w \bar{a} w$ in the nominative and $y \bar{a} ?$ in the genitive in the $\mathrm{CE}$. But this is a quirk of the $\mathrm{CE}$, and examination of early Quranic manuscripts reveals that both spellings with and without the glides are attested (van Putten and Stokes 2018, 172-176). While previously, Van Putten \& Stokes (2018, 159, 16of.) have interpreted this as evidence that case vowels in construct could optionally be lost, I now believe that a more natural interpretation of this data is to see this as related to the special status of this word-final hamzah after $/ \bar{a} /$.

From Quranic rhyme it is clear that the hamzah was retained in this position, thus الدعا Q2:38) clearly rhymes with other words that end in /āG/, which suggests a pronunciation /ad-duYā?/. Moreover, انشا (Q56:35) stands in an /āGā/ rhyme, thus suggesting that the indefinite accusative was pronounced with final /āa-āa, i.e. /inšāāā/.

Presumably those forms that lack the glides are cases where the stemfinal hamzah (spelled with the Palif) was retained. While those that show a glide have optional elision of the hamzah in this non-word-final position. The paradigm of nouns of this type must therefore be something along these lines as shown in the table below. 


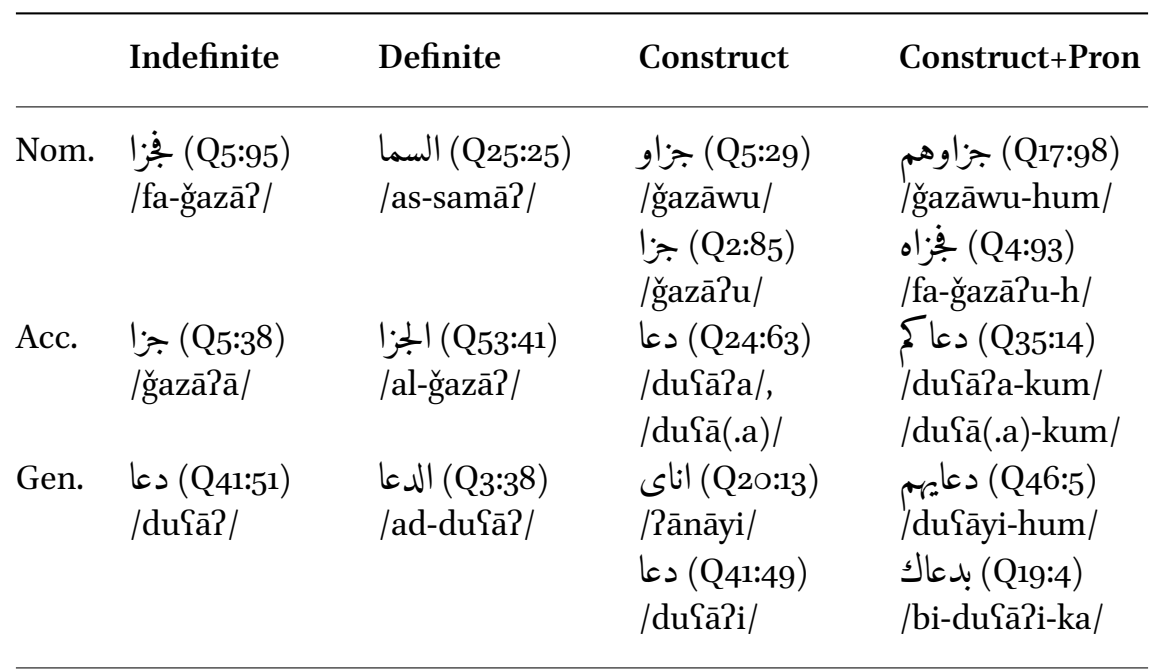

The noun ?awliy $\bar{a}$ ? 'allies; protectors' is of exceptional status. While it is a noun that historically end in $-\bar{a}$ ?, when the noun stands in construct the glide for the case vowel never appears, not when it stands in construct with a noun, nor when a pronominal suffix follows. This idiosyncrasy is not retained in the $\mathrm{CE}$, but can be reconstructed for the UT, see B.24 (see also Nöldeke et al. 2013, 422). It thus seems that this noun has merged with nouns that end in $-y \bar{a}$ such as /ad-dunyā/ 'world' ( passim), الحوايا /al-ḥawāyā/ 'intestines' (Q6:146) and خطيكم) /xațāyā-kum/ 'your sins' (Q2:58).

\begin{tabular}{|c|c|c|c|c|}
\hline & Indefinite & Definite & Construct & Construct+Pron \\
\hline Nom. & $\begin{array}{l}\text { اوليا (Q46:32) } \\
\text { /awliyā/ }\end{array}$ & & $\begin{array}{l}\text { اوليا (Q5:51) } \\
\text { /awliyā/ }\end{array}$ & $\begin{array}{l}\text { اوليهم (Q2:257) } \\
\text { /awliyā-hum/ }\end{array}$ \\
\hline Acc. & $\begin{array}{l}\text { اوليا (Q3:28) } \\
\text { /awliyā/ }\end{array}$ & & $\begin{array}{l}\text { اوليا (Q4:76) } \\
\text { /awliyā/ }\end{array}$ & $\begin{array}{l}\text { اولين (Q3:175) } \\
\text { /awliyā-h/ }\end{array}$ \\
\hline Gen. & $\begin{array}{l}\text { اوليا (Q11:20) } \\
\text { /awliyā/ }\end{array}$ & & & $\begin{array}{l}\text { اوليهم (Q6:121) } \\
\text { /awliyā-hum/ }\end{array}$ \\
\hline
\end{tabular}

This shift of category seems to be unique to this noun, ادعييه//Radhiyāyi-hum/ 'adopted sons' (Q33:37) is consistently spelled with the glide for the genitive in early manuscripts (see B.25). 


\section{A.4.12 Confusion between Subjunctive and Apocopate}

There is one example in the QCT where we find confusion between the subjunctive and the apocopate. The following verse uses an apocopate stem, in a clearly subjunctive context:

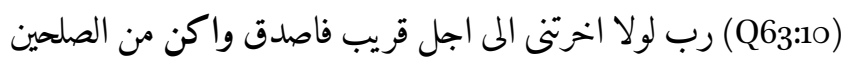

/rabb- $\varnothing$, lawlā axxarta-nī ilā ajal qarīb fa-așșaddaq wa-akun min aṣ-ṣālihīn/

My lord, if only you would delay me for a brief term so I would give charity and be among the righteous ${ }^{93}$

\section{A.4.13 Partial Merger of III-P Verbs and III-y/w Verbs}

In Classical Arabic grammar III- $w / y$ verbs and III-? are kept clearly distinct. This is, as far as we can tell from the defective spelling, not the case in Quranic Arabic, where we see a certain amount of merger of the two stem types. This merger is certainly less complete than it is in the modern dialects, but nevertheless we can deduce mergers from the Qст that did not take place in Classical Arabic.

G-stems of III- $?$ verbs are still clearly distinct from III- $y$ and III- $w$ verbs, e.g. قرات /qarāt/ 'you recited' (Q16:98) vs. نجوت /nağawt/ 'you fled' (Q28:25) and قضيت /qadayt/ 'you decided' (Q4:65), and even in derived stems there are clear examples where they are distinct, e.g. نبات /nabbāt/, or /nabba?at/ 'she informed' (Q66:3), نباتكما /nabbātu-kumā/ 'I informed you' (Q12:37); اخطاتم /axṭātum/ 'you have sinned' (Q33:5); امتلات/imtalāt/ 'you filled' (Q50:30).

In the imperfect stem and nominal derivations, however, these verbs merge to a large extent throughout the whole paradigm. With the loss of the ?, wordfinal $i$ yielded $-\bar{\imath}$, merging in most places with word-final $-\bar{\imath}$ of final weak roots. This can be clearly seen in some of the derived stems of final glottal stop roots that in the imperfect plural forms as well as the participial plural forms have merged with the III- $y / w$ verbs.

$$
\begin{aligned}
& \text { يستهزى /yastahzī/ (Q2:15) > "yastahzi?u } \\
& \text { مستهزون /mustahzūn/ (Q2:14) > "mustahzi?ūna }
\end{aligned}
$$

93 It is interesting to note here that, while most reading traditions simply follow the rasm and read this word as an apocopate ?akun, ?abū Yamr ignores the rasm and reads it as the Classically normative ?akūna (Ibn al-Ǧazarī, § 4401). 


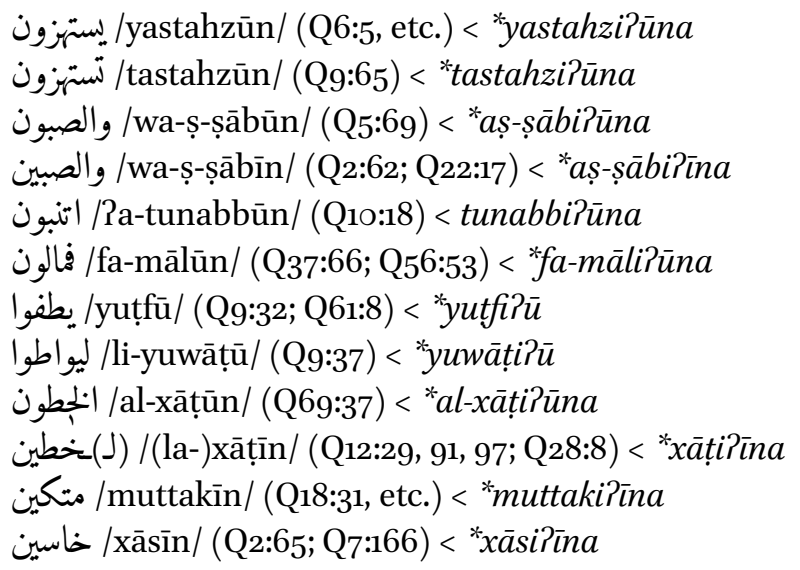

This merger has led to some amount of disagreement whether certain verbs are III- $y$ or III- $?$ among the canonical readers, see $\S 6.5 .5$ for a discussion.

Words ending in *a?ūna are technically ambiguous in terms of their interpretation, due to the tendency to not write double $w \bar{a} w$ sequences for representing / wü/ (see A.2.2). It however stands to reason that these would have merged to /-awn/, e.g.

$$
\begin{aligned}
& \text { يطون /yațawn/ (Q9:120) > *yaṭa?ūna } \\
& \text { يقرون بطون /yaqrawn/ (Q10:94; Q17:71) > "yaqra?ūna } \\
& \text { يدرون /yadrawn/ (Q13:22; Q28:54) > "yadra?ūna } \\
& \text { مبرون /mubarra?ūn/ (Q24:26) > *mubarra?ūna }
\end{aligned}
$$

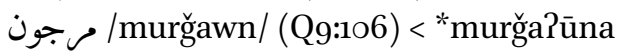

In the Sarabiyyah, the apocopate and imperative would be places where III-? and III- $w / y$ verbs would remain distinct, even if one were to pronounce them with the loss of hamzah. The imperative of صs șalla 'to bless' would be șalli 'bless!', whereas the imperative of نبأ nabba?a 'to inform' would be نبئ nabbi? which with dropping of the hamzah should yield nabbi.

In the QCT we see that a merger between the two stem types is under way, no doubt due to their complete merger in the imperfective and subjunctive stems. The table below illustrates the examples of apocopates and imperatives of historically III-? verbs and how they appear in the QCT. 


\begin{tabular}{|c|c|c|}
\hline \multicolumn{2}{|l|}{ QCT } & \multirow{2}{*}{$\begin{array}{l}\text { Classical Arabic } \\
\text { أَرجزئَه }\end{array}$} \\
\hline ارجه (Q7:111; Q26:36) & /arği-h/ & \\
\hline نبنا (Q12:36) & /nabbi-nā/ & ل \\
\hline نبى (Q15:49) & /nabbī/ & نَبَُّْْ \\
\hline نبيهم (Q15:51; Q54:28) & /nabbī-hum/ & 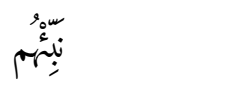 \\
\hline انبيهم (Q2:33) & /anbī-hum/ & 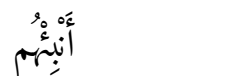 \\
\hline
\end{tabular}

One final verb could perhaps be added here, namely ننسه (Q2:106), which is either read nunsi-hā, an apocopate of Pansā 'to cause to be forgotten' or nansa?$h \bar{a}$ from nasa?a 'to cause to be delayed' (Ibn al-Ǧazarī, §2720). If the latter reading is correct, this would be yet another hamzated apocopate that appears to function as a final weak verb. But * $a$ ? usually does not show this merger, e.g. / إ مينبا ا ا ا / lam yunabbā/ 'recite!' (Q17:14; Q96:1, 3). Semantically, nunsi-hā seems like a better fit in this verse: ما ننسخ من whatever we abrogate from a verse or cause it to be forgotten we bring one better or equal to it.", and thus I think it is better taken as the regular outcome of a final weak verb.

Finally, the verb hayya?a 'to make ready' is consistently spelled with a final Palif in early Quranic manuscripts: hayyi? هيا (Q18:10); yuhayyi? يهيا (Q18:16). This spelling should be reconstructed for the Uthmanic archetype, but its interpretation is not very clear, for a suggestion and other words with such spellings, see Van Putten $(2018,115)$.

\section{A.4.14 Pausal Imperatives/Apocopates of III-y/w Verbs Iqtadih, yatasannah} III- $w / y$ apocopates and imperatives throughout the Quran are consistently without any reflex of the final radical, thus we see, e.g. يوم /yarmi/ 'throws' (Q4:112), يدع/yadY(u)/ 'invokes' (Q23:117), يلق /yalq(a)/ 'meets' (Q25:68); ايت /īt(i)/ 'come!' (Q10:15), اد /udY(u)/ 'invoke!' (Q2:68).

94 This word is spelled نبينا in the CE, but in early Quranic manuscript نبنا is regular. See B.26 for an overview.

95 Most manuscripts have the rasm انبيهم but DAM O1-32.1 has نهil. This latter rasm is not 
However, the only two times that an imperative and apocopate occur in pause, these stems are suffixed with a final $h \bar{a} r:$ : فبهديه اقتده /fa-bi-hudē-hum iqtadih\#/ "so follow after their guidance." (Q6:90), ${ }^{96}$ which is followed by the قلح pausal sign in the CE, which indicates an optional pause, with a preferقل بل لبثت مايه عام فانظر الى /qāl bal labițt miyah Yām fa-nzurur ilā țaYāmi-k wa-šarābik lam yatsannah\#/ "He said: Nay, you have remained for a hundred years, look at your food and your drink; it did not age." (Q2:259), which is followed by the ص pausal sign in the $\mathrm{CE}$, which indicates an optional pause, with a preference towards continuing. ${ }^{98}$ Based on these two examples it seems that in Quranic Arabic imperatives and apocopates received $/ \mathrm{h} /$ in pause.

It is worth noting that the fact that this $h \bar{a}$ ? only shows up in pausal position, is yet another piece of evidence that 'pausal spelling' is not a governing principle in Quranic orthography. Had that been the case, all apocopates and imperatives should have received a final $h$, not just the one that stand in a pausal position.

\section{A.4.15 Partial Merger of the I-P and I-w Verbs in Derived Stems}

Due to the loss of the hamzah (see §5.2) D- and L-stems of verbs with a ? as their initial consonant merge with D- and L-stems of verbs with $w$ as their initial consonant, e.g. "Yu?axxiru-hum > يوخرهم/yuwaxxiru-hum/ 'he gives respite to them' (Q14:42); 'yu?āxidu > يواخذ/yuwāxid_/ 'he would punish' (Q35:45). Such verbs usually remain distinct in the perfect where you get forms like *Paxxara $>>>$ ا ا $/$ Raxxar/ 'left behind' (Q75:13). The partial merger of these verb types is no doubt the origin of the pseudocorrect use of hamzah in mu?șadah for müșadah (§6.4.2).

A more pervasive merged with I- $w$ is found in the Gt-stem of the verb ?ax$a d a$, which is treated as a I-w in the QCT. This idiosyncrasy also finds its way into Classical Arabic, e.g. اتخذل /ittaxad/ 'he took' (e.g. Q18:4). Other Gt stems of

common, but it is consistent with the reading of al-Ḥasan al-Bașrī Panbi-himī (Ibn Xālawayh muxtașar, 4).

96 Ibn Yāmir treats this final $h \bar{a}$ ? as a pronoun, reading it iqtadi-hi or iqtadi-hī (Ibn al-Ǧazarī, $\S 2375)$. This reading is grammatically rather awkward. It is difficult to take it as a resumptive pronoun of the preceding object (bi-hudā-hum) since that object is marked with bi-, thus we would expect iqtadi bi-hī rather than iqtadi-ȟ̆. Ibn Muḡāhid (262) shared this sentiment and explicitly calls it a mistake (wa-hā $\underline{d} \bar{a} \dot{g} a l a t ̦ u n)$ because this is a pausal $h \bar{a} ?$, not a pronoun.

97 See also Sağāwindī (Silal al-Wuqūf, 333).

98 See also Sağāwindī (Silal al-Wuqūf, 482). 
I-? verbs continue to behave distinctly from I-w verbs, e.g. لا ياتل / lā yātal/ 'may

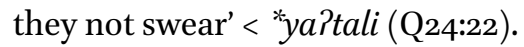

\section{A.4.16 /yak/besides/yakun/}

The verb كان / kān/ 'to be', has an anomalous form in the apocopate. Besides the regular stem form ك which is identical to that of Classical Arabic, quite often we find the form ك. Van Putten \& Stokes (2018, 168-170) argue that this is best understood as the regular outcome of this verb in Quranic Arabic. As word-final nunation and case vowels were lost, the word final *-un of *yakun would also regularly be lost, yielding /yak/. The long form is then an analogically restored version of the apocopate.

\section{A.4.17 'raPaya 'to See' and "na?aya 'to Be Distant'as}

The regular spelling of the verbs ra? ' 'to see' and na? ' 'to be distant', both historically final weak verbs with a medial hamzah, is $ا$ ر and respectively in the QCT. Their orthographic behaviour suggests that they have merged with hollow

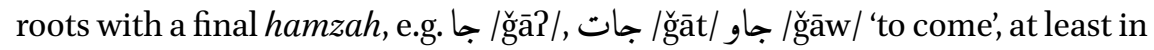
the 3 rd person masculine singular and plural forms, hence we find spellings 1 ,

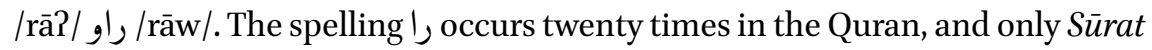
al-Nağm attests the form راى (Q53:11, 18), which at least in the first verse seems to be the use of a dialectal form / $\mathrm{ra} \overline{\mathrm{e}} /$ to accommodate the rhyme. The exact interpretation of the unusual behaviour in this Sūrah, however, should not distract us from the fact that the regular Quranic form is 1 , which is not likely to have been a spelling for /ra?ē/.

How exactly $\mid$, and took on the shapes that they have is not entirely obvious. One might imagine that at an earlier stage of Quranic Arabic, the " $y$ and ${ }^{*} ?$ were regularly metathesized, "ra?aya $>$ "raya?a which then regularly yielded /rā?/. Alternatively, one might imagine that the intervocalic hamzah had dropped yielding "ra?aya > rāya which then, similar to *samāy 'sky' shifted its word final $y$ to ?, likewise yielding /rā?/.

In the former development one would expect the verb to have completely merged with verbs of the type /ğā?/, in which case one would predict the first and second person forms to be like جيت/ḡit/. But this does not seem to be the case. The Cairo edition attests both اريت إيت 'did you see?' (e.g. Q18:63) and رايت 'you saw' (e.g. Q47:20). ${ }^{99}$ In Early Quranic manuscripts it is not at all uncommon to only see the spelling ريت, but رايت spellings do occur. Considering these

99 There is a certain conditioned distribution between these two spellings in the Cairo edition, but this appears to be absent in early Quranic documents (see van Putten 2018, 107 f.). 
spellings, it seems that the suffixed forms were probably /rāy-t/ 'you saw', etc. In which case the second scenario which requires hamzah to be lost before the * $\bar{a} y$ $>\bar{a}$ ? shift, becomes more probable. This specific behaviour with partial merger, rā?a but raiaytu (or rāytu), is exactly what is reported by al-Farrā? as being a typical Hijazi isogloss $(\S 5 \cdot 11)$. 